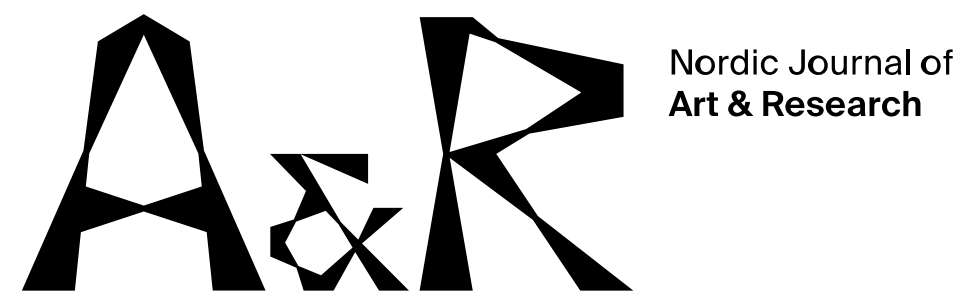

\title{
Kopiering og kulturelle referanser som verktøy i bildeskaping
}

\section{Opphavsrettslige utfordringer i undervisningen}

\author{
Silje Bergman ${ }^{1}$ \\ Universitetet i Sørøst-Norge
}

\section{Sammendrag}

Kopiering som verktøy i bildeskapende prosesser, og etiske og opphavsrettslige utfordringer i den forbindelse, er tema for denne artikkelen. For å undersøke temaet er det utviklet et undervisningsopplegg der studenter løser oppgaver gjennom å bruke og kopiere eksisterende verk. Eksempler fra studiens visuelle og skriftlige empiri presenteres i denne artikkelen, og er grunnlag for diskusjon om hvordan teori og kritisk refleksjon kan øves i studenters bildeskaping. Jeg argumenterer for at denne type undervisning og skapende prosesser kan øke forståelsen av teori, når den må reflekteres over gjennom bildeskapende prosesser. Visuelle empiriske resultater fra studien har vist seg hensiktsmessige som utgangspunkt for meningsutveksling og utvikling av kunnskap. Artikkelen gir et bidrag til formidling av kunnskap om opphavsrett i dagens visuelle delingskultur, spesielt med tanke på å forstå kopiering og kulturelle referanser i didaktisk kontekst.

Nøkkelord: Kopiering, kulturelle referanser, interpikturalitet, opphavsrett, bildeskaping, digital litterasitet, digital delingskultur 
Silje Bergman. Kopiering og kulturelle referanser som verktøy i bildeskaping

\section{Innledning}

Kommunikasjon gjennom bilder er et språk vi lærer i oppveksten og utvikler videre som voksne. Noe ved det visuelle språket læres eksplisitt i undervisning, mens andre sider tilegnes gjennom erfaring. Kompetanse i det visuelle språket blir stadig viktigere ettersom digitale kommunikasjonsformer og sosiale medier i økende grad kommuniserer med bilder i en visuell delingskultur (Banks, 2007; Jurgenson, 2019), og evnen til å tolke visuelle budskap må derfor trenes (Häikiö, 2007, s. 267). De visuelle uttrykkene vi finner i sosiale medier, spill, film og TV kommuniserer ofte gjennom «remediation» (Bolter \& Grusin, 1999), et begrep som viser til hvordan eldre uttrykk re-medieres i nye verk. Det tekniske ved å finne og bruke for eksempel eksisterende bilder er lett, mens hvordan bilder involveres i den sosiale kommunikasjonen er mer komplekst enn noensinne (Jurgenson, 2019). Bruk og referanser til tidligere kunst er en naturlig og selvfølgelig del av en kreativ prosess, og originalitet handler ikke nødvendigvis om å skape noe ingen før har sett. Fra et perspektiv som hegner om kulturell produksjon kan det bli et dilemma at mulighetene for kopiering, plagiering, re-mediering, re-kontekstualisering, remiksing etc. øker i ulike typer kreative prosesser, mens det samtidig er viktig å beskytte skapere av kunstneriske uttrykk mot krenkelser, og opprettholde insentiver til videre kulturell produksjon. Med dette som bakteppe betyr det at vi har et økende behov for kunnskap om bruk av visuelle uttrykk, og hvilke rettigheter visuelle åndsverk beskyttes av. Den norske opphavsretten til åndsverk regulerer hva vi kan gjøre med andres skrevne tekst, men den begrenser også vår tilgang til å bruke andres visuelle verk. For eksempel hvordan andres malerier eller fotografier eller digitale arbeider kan brukes i nye skapende prosesser. A tolke hva som i praksis er lov innenfor åndsverklovens rammer kommer med trening. Det finnes ingen oppskrift fordi hvert tilfelle er unikt og krever en skjønnsmessig vurdering (Bergman, 2019, s. 4). I denne artikkelen har jeg utforsket nettopp de dilemmaene som oppstår når studenter skaper nye verk gjennom å bruke eksisterende verk, og jeg har sett på hva slags refleksjoner og kunnskap dette kan utvikle.

I dag kan de fleste være både brukere og skapere av visuelle uttrykk, og tolkning av opphavsrettigheter gjelder derfor ikke bare kunstnere og selskaper som eier rettigheter til kjente kunstneriske uttrykk. Det oppstår nye utfordringer med kopiering i en digital delingskultur på grunn av mulighetene til å manipulere og publisere på digitale plattformer (Bergman, 2019). Fagfornyelsen i de nye læreplanene (Utdanningsdirektoratet, 2019b) vitner om økt behov for at opphavsrett behandles i fagfeltene. Haakonsen (2017) og Stana (2017) har belyst sider ved problematikken knyttet til kunst og håndverksfag, og det tydeliggjøres at kunnskap om hva som er 
Silje Bergman. Kopiering og kulturelle referanser som verktøy i bildeskaping

lovlig bruk av bilder i undervisningssammenheng er underkommunisert blant lærere i dag (Bjerke, 2019). Det er nødvendig å forstå rettighetene et åndsverk beskyttes av for å kunne bruke felles kulturell arv og andres verk på en ansvarlig måte, og dette bør være en sentral problemstilling både i Kunst og håndverk som skolefag, blant lærere og i lærerutdanninger.

Et sentralt begrep i denne sammenhengen er digital dømmekraft, som ble innført i rammeverket for grunnleggende ferdigheter i læreplanene for grunnskolen. Begrepet omfatter opphavsrett, personvern og kildekritikk (Utdanningsdirektoratet, 2012). Utdanningsinstitusjonenes ansvar for å formidle kunnskap og gode holdninger om opphavsrett får stadig mer oppmerksomhet i den offentlige debatten (DelRett.no, 2010, 2017, 2019; Granlund, 2015; Hannemyr, 2018; Solvig, 2010). Skolen har ansvar for at elever får den nødvendige kompetanse for utdannings- og samfunnslivet i dag og i fremtiden (Giæver et al., 2014, s. 10), noe som i dag, med selvfølgelighet, inkluderer digital dømmekraft i en visuell delingskultur. Kompetansen må inn i lærerutdanningen fordi fremtidens lærere ikke bare skal formidle kunnskapen, men også er rollemodeller når de bruker eksisterende verk.

I denne artikkelen er læreplanene for kunst og håndverk i grunnskolen relevante, selv om studien tar utgangspunkt i studenter i en lærerutdanningsinstitusjon. Det er ulike pedagogiske tradisjoner knyttet til elever- og studenters læring, men studentene i denne studien forberedes selv til rollen som lærere, og skal således forholde seg til denne profesjonens rammeverk. I studien undersøkes derfor muligheter og begrensninger som oppstår i skjæringspunktet mellom lovverk og utdanning, når studenter bruker eksisterende kunstverk i egen bildeskaping. Målet med denne vinklingen er å styrke lærerstudenters faglige argumentasjon når de selv skal undervise om og med eksisterende verk.

I artikkelen stilles to forskningsspørsmål:

1) Hvordan kan kopiering og kulturelle referanser brukes som interpikturelle verktøy $i$ studenters bildeskaping?

Dette spørsmålet undersøkes gjennom et undervisningsopplegg og praktiskestetiske øvelser.

2) Hvordan kan studenter utvikle evne til å gjøre opphavsrettslige vurderinger gjennom å reflektere over egne interpikturelle prosesser?

Dette spørsmålet undersøkes gjennom studentenes egne refleksjoner knyttet til den skapende prosessen. 
Silje Bergman. Kopiering og kulturelle referanser som verktøy i bildeskaping

Begrepet interpikturalitet som brukes i problemstillingen, handler om hvordan bilder kan være sammensatt av, og kommunisere med tidligere visuelle verk. Begrepet ble lansert av professor og kunsthistoriker Jorunn Veiteberg $(1982,2009)$ som en omformulering av den internasjonale termen intertextuality. Psykoanalytiker, Julia Kristeva, definerte intertextuality som hvordan ulike tekster fra ulike tider er vevet sammen (1980). Interpikturalitet har også paralleller til det kunstkritiker Nicolas Bourriaud definerer som postproduction (2005). Postproduksjons-kunstnere gjenbruker eksisterende kulturelle materialer (ikke nødvendigvis åndsverk), og omdefinerer dette innenfor en kunstkontekst. Begrepet interpikturalitet er ikke forankret i en etablert kunstverden. Jeg bruker det her som en bredere visuell kommunikasjon mellom kulturhistoriske referanser og symbolikk fra eksisterende verk sammen med skaperens nye formgiving og innhold. Det omfatter visuelle referanser, sitering fra kunstverk, og kan grense til kopiering, men betinges i utgangspunktet ikke av en opphavsrettslig vurdering. Regler vedrørende opphavsrett er sentrale for forskningsspørsmålene i denne artikkelen, og jeg knytter disse sammen som interpikturell litterasitet.

\section{Teoretisk grunnlag}

\section{Opphavsrett}

I Norge er det Lov om opphavsrett til åndsverk (Åndsverkloven, 2018) som regulerer opphaveres rettigheter til å bestemme over eget verk. Et verk er i denne lov definert som litterære eller kunstneriske arbeider som gir uttrykk for original og individuell skapende åndsinnsats med verkshøyde. Det betyr blant annet at et åndsverk ikke kan være skapt av naturen alene. Lovens formål er på den ene siden å gi insentiv til kulturell produksjon, nemlig at opphaver har enerett til å tjene penger på og bestemme over sine verk. Et åndsverk kan derfor ikke kopieres eller brukes av andre uten lov. På den andre siden avgrenser åndsverkloven opphavers rettigheter for å ivareta en rimelig balanse mellom begrensninger for allmennheten og allmennhetens tilgang på kulturelle verk.

I denne artikkelens kontekst er det enkelte av åndsverklovens paragrafer som er mer relevante enn andre. Disse regnes som avgrensninger av opphavers rettigheter, og jeg vil kort redegjøre for dem i det følgende. Den første er Bearbeidelser (Åndsverkloven, 2018, § 6), som sier at den som oversetter, bearbeider eller overfører et åndsverk til en annen litterær eller kunstnerisk form, har opphavsrett til dette nye verket, men kan ikke bruke det i strid med opphavsretten til originalverket. Denne bestemmelsen er viktig for at ikke opphavsrett skal komme i veien for 
Silje Bergman. Kopiering og kulturelle referanser som verktøy i bildeskaping

inspirasjoner og nyskaping gjennom å benytte eksisterende verk. Magnus Stray Vyrje, opphavsrettsadvokat og forfatter av juridiske kommentarer til den nye åndsverkloven legger vekt på den «estetiske opplevelsen» av verket (2012), et verk må «erfares estetisk» (2017). Han understreker at det er en forskjell mellom kopi og inspirasjon «Kopien er underlagt opphavsmannens enerett fordi den, helt eller delvis, fremkaller samme estetiske opplevelse som forelegget. Inspirasjonen faller utenfor fordi den kommuniserer noe uttrykksmessig eget» (Vyrje, 2012). Med en slik forståelse vil blant annet visuelle parafraser kunne tolkes som lovlige gjengivelser av eldre verk, og en pastisj som en lovlig stil-kopi.

Blant de såkalte fribruksrettighetene finner vi Kopiering til privat bruk (Åndsverkloven, 2018, § 26), som tillater eksemplarfremstilling av offentliggjort verk til privat bruk, så lenge det ikke skjer i ervervsøyemed, og Sitat (Åndsverkloven, 2018, § 29) som sier at det er lov til å sitere fra offentliggjorte visuelle verk, i likhet med litterære, så lenge det gjøres i samsvar med god skikk og i den utstrekning formålet betinger. Det betyr at man ikke kan sitere på en måte som krenker verk eller opphaver. I denne artikkelen er det relevant å ta med Fri bruk av verk ved undervisningsvirksomhet (Åndsverkloven, 2018, § 43), som sier at et utgitt verk kan overføres til allmennheten ved undervisning. Begrepet 'overføring' som brukes her kan være vanskelig, fordi det handler om å vise et verk i en undervisningssammenheng, men for å vise må man gjerne fremstille et eksemplar, og det er etter åndsverkloven en rettighet som tilfaller opphaver (Åndsverkloven, 2018, § 3). For filmverk, sceneverk og kringkasting gjelder i tillegg andre regler. Vernetid (Åndsverkloven, 2018, § 11) er vesentlig, da denne stadfester hvor lenge et åndsverk er vernet. Dette avgrenses til 70 år etter opphavers død. Etter denne tid faller alle opphavers verk «i det fri» (Torvund, 2012;

Åndsverkloven, 2018) hvilket betyr at de kan brukes og bearbeides fritt av alle uten å be om lov, men kan ikke brukes på en støtende måte.

Den amerikanske jusprofessoren og grunnleggeren av Creative Commons lisenser, Lawrence Lessig, kritiserer de store mediekonsernene for å legge press på en strengere opphavsrettspraksis, og sier det skader den grunnleggende friheten som er nødvendig for kreativitet. Han mener følgene av for strenge opphavsrettsregler er at nye generasjoner blir mindre vare for viktige mekanismer i loven, og ikke forstår hvorfor andres arbeid ikke kan kopieres. Dagens mulighet til å dele verk på digitale plattformer gjør det lett å bryte åndsverkloven (Lessig, 2009, s. 103), og dette er utfordringer som må adresseres i utdanningen. Lessigs perspektiver på remiksing som vesentlig i den oppvoksende generasjonens kreative uttrykksformer, og som helt sentralt for en digital delingskultur, er viktig å ta med i denne sammenhengen. De er 
Silje Bergman. Kopiering og kulturelle referanser som verktøy i bildeskaping

sterkt debattert, og hans forsvar av brukernes rettigheter står ikke uimotsagt. Margie Borschke, førstelektor i journalistikk og media, argumenterer blant annet for at Lessigs polemikk om remiks som en digital prosess er for grunn. Den vitner om lite kunnskap om de ulike kopieringspraksisene som hverken er nye eller utelukkende digitale fenomen, men hvor referanser til eksisterende kulturuttrykk har vært en grunnleggende mekanisme (Borschke, 2011).

\section{Læring}

Perspektivet på læring i denne studien er farget av John Deweys læringssyn, ofte referert som «learning by doing», og sosialkonstruktivismens grunnidé om at kunnskap bygges gjennom sosiale konstruksjoner (Hellesnes, 2001). Det legger som premiss at læring skjer gjennom handling. I følge professor Kai Hakkarainen og førsteamanuensis i digital læring, Sami Paavola, er grunnlaget for en slik holdning at læring kommer som et resultat av aktivitet, erfaring og refleksjon, og ikke kun er konseptualisert gjennom prosesser som skjer i enkeltpersoners sinn (2005).

Samspillet mellom de ulike kunnskapsformene eller mellom kunnskap og aktivitetene studentene deltar i, er en forutsetning for at læring skjer i produksjon av kunnskap (Paavola et al., 2004). Analysen av læringen i denne studien forankres i at praktisk og sosial virksomhet kan utvikle studenters kritiske refleksjoner, og at deres nye erfaringer og holdninger blir prøvet og speilet innenfor sosiale rammer (Dale, 2001; Dewey \& Wrang, 2005). Læring sees derfor ikke kun som en rasjonalistisk prosess der kunnskap overføres uten at det aktivt erfares og reflekteres over.

Professor Liv Merete Nielsen trekker frem at fagmiljøet for kunst og håndverk er opptatt av at gjøringen ikke er nok i seg selv til å skape god læring (2019, s. 37). Samtaler og refleksjon knyttet til det som gjøres er like viktige deler i konstruksjonen av kunnskap. I denne studien anvendes disse perspektivene for å se muligheter til å bruke kopiering som verktøy, og hvordan refleksjonen og dialogen som oppstår i den skapende prosessen bidrar til læring. Et viktig aspekt ved slik refleksjon er forholdet mellom det å skape og kritisk forståelse. Professor David Buckingham løfter frem denne dynamikken som avgjørende for læring, og for å utvikle et kompetent visuelt språk (Buckingham, 2006, s. 274).

\section{Digital litterasitet $i$ en digital delingskultur}

Forskning indikerer at ungdommers bruk av sosiodigitale teknologier er svært ulike. Vestlige ungdommer er storbrukere av digital teknologi som sosiale medier, og omtales ofte som digitalt innfødte. Til tross for dette er det få som kjenner eller bruker teknologien på kreative og utviklende måter (Hakkarainen et al., 2015). 
Silje Bergman. Kopiering og kulturelle referanser som verktøy i bildeskaping

Digitale verktøy muliggjør nye og mer gjennomgripende måter å skape på enn det som var mulig med analoge verktøy (Buckingham, 2006, s. 274). I det digitale ligger samtidig en større fare for å bruke andres arbeid på krenkende måter eller ubevisst bryte lovverk i en visuell delingskultur. Buckingham forstår digital litterasitet fra et medieutdanningsperspektiv som er relevant for denne studien. Han hevder at god utdanning er avhengig av lærere som anerkjenner kunnskap studenter allerede har om digitale medier, og at det i dag er alvorlige begrensninger i studenters digitale litterasitet (Buckingham, 2006, s. 274).

Digital litterasitet innebærer altså kompetanse i å bruke digitale verktøy mer avansert enn kun for sosial kommunikasjon. For å være litterat i en digital sfære settes det krav til noen bestemte kompetanser og ferdigheter. Europakommisjonen har definert 21 digitale kompetanser i et rammeverk på 5 hovedområder, der kompetansene vurderes som nødvendige for å være en kyndig digital borger. Kunnskap om opphavsrett pekes på som relevant kompetanse under punkt 3. i rammeverket: Content creation (Ferrari, 2013, s. 27), og defineres som å forstå opphavsrett og ulike typer lisensiering når man skaper innhold og bruker dette i egen digital produksjon (Ferrari, 2013, s. 25-28; lordache et al., 2017, s. 20). Rammeverket Profesjonsfaglig digital kompetanse (PfDK) er et tilsvarende retningsgivende dokument som definerer den kompetansebyggingen lærerutdannere, lærere og lærerstudenter har ansvar for når de underviser med digitale verktøy i digitale omgivelser. PfDK består av 7 kompetanseområder, hvor området Etikk definerer innsikt i lovverk, regler for opphavsrett og digital dømmekraft som nødvendig for å bli en profesjonsfaglig digitalt kompetent lærer (Utdanningsdirektoratet, 2018). Lærere etterspør stadig oftere kunnskap om etiske sider, som opphavsrett, ved bruk av bilder i undervisning og på digitale plattformer (McClimans, 2018; Rian, 2018). I denne artikkelen undersøker jeg opphavsrettsperspektivet med utgangspunkt i studenters bildeskapende prosesser, og drøfter om slike praksiser kan bidra til å utvikle den kompetansen i digital litterasitet som gjør studentene til ansvarlige brukere og produsenter av visuelt og digitalt materiale.

\section{Dybdelæring og digitale ferdigheter i en digital delingskultur}

Utvikling av analytisk tenkning, kritisk vurdering og erfaringsbasert læring er viktige byggesteiner for det danningsmandatet utdanningsinstitusjonene har. Dypere forståelse og kritisk tenkning har fått en sentral rolle i det nye læreplanverket for 2020 (Kunnskapsdepartementet, 2017). Både overordnet del og læreplanene for kunst og håndverk har et mer uttalt fokus på at digital teknologi skaper nye muligheter og 
Silje Bergman. Kopiering og kulturelle referanser som verktøy i bildeskaping

utfordringer, og at vi trenger kunnskap for å håndtere det nye ansvaret som følger med denne utviklingen (Bergman, 2019; Kunnskapsdepartementet, 2017).

Dybdelæring har fått en sentral posisjon i Fagfornyelsen. Begrepet innebærer refleksjon over egen læring og tid til å lære noe så godt at man forstår sammenhenger (Gilje et al., 2018; Utdanningsdirektoratet, 2019a). I fremtiden vil utdanning være avhengig av gode redskaper for å overføre kunnskap fra ett felt til å løse nye problemstillinger, kanskje i et helt nytt fagfelt, og kompetanse i å oppdage og bruke kunnskap i nye sammenhenger.

Med dette fokuset blir også de grunnleggende ferdighetene omskrevet og mer tilpasset de utfordringene barn og unge møter i dagens digitale samfunn og delingskultur (Bergman, 2019). For eksempel viser høringsdokumentet for læreplanen i Kunst og visuelle virkemidler at lærere etterspør en mer bevisst formulering av opphavsrett i grunnleggende ferdigheter. I digitale ferdigheter presiseres opphavsrett og personvern på en tydeligere måte, blant annet som evne til å navigere i en bruker- og delingskultur i digitale og sosiale medier (Utdanningsdirektoratet, 2019c). I læreplanen for grunnskolefaget Kunst og håndverk er de samme ferdighetene ytterligere presisert med hensyn til bruk av andres åndsverk i skapende arbeid. Det legges nå mer vekt på kjennskap til regler om opphavsrett og personvern når man bruker egne eller andres bilder, filmer og skapende arbeid (Utdanningsdirektoratet, 2019b). Det fokuseres også på at digitale ferdigheter i kunst og håndverk innebærer bruk av ulike digitale verktøy, medier og ressurser som kilde til inspirasjon og i skapende arbeid. Digitale ferdigheter $\mathrm{i}$ undervisningen skal romme den praktisk-estetiske siden når elever bruker eksisterende verk og kulturuttrykk, og samtidig den etiske siden ved å opptre respektfullt overfor opphaver til verket.

\section{Tidligere forskning på kopiering i undervisningsopplegg}

To gode eksempler på undervisningsformer som tar opp kopiering og kulturelle referanser som verktøy, beskrives av henholdsvis professor i kunstfagdidaktikk Helene Illeris, og poet og underviser i litteratur Kenneth Goldsmith. I Copying-You Just Aren ‘t Supposed to Do That! drøfter Illeris en kunst og håndverklærers opplevelser fra et undervisningsopplegg (2000; Larsen, 1991). Læreren, Larsen, har bearbeidet en tradisjonell mester/lærling-metode. Han gjør et poeng ut av at dersom man vil få elevene til å bade i en sjø av verdens kunstverk, må de først få dyppe tærne, ellers vil de drukne (Illeris, 2000; Larsen, 1991). Undervisningsformen gikk i praksis ut på at Larsen lot elevene velge et verk fra skolens kunstbøker, magasiner, 
Silje Bergman. Kopiering og kulturelle referanser som verktøy i bildeskaping

kalendere osv. De ble utfordret til å kopiere det valgte bildet så nøyaktig de kunne, for hånd, ved å observere mesterens fargebruk, motiv, komposisjon og penselstrøk. Den første reaksjonen fra elevene var at det var ulovlig, og at å ettergjøre en mesters verk var en umoralsk handling. I løpet av møysommelig kopieringsarbeid oppdaget imidlertid elevene at deres arbeid var godt utført, og i tillegg uttrykte de sin personlige stil med farge og komposisjon (Illeris, 2000; Larsen, 1991).

Det andre eksempelet er skrivekurset Uncreative Writing (Goldsmith, 2011) hvor universitetsstudenter ble trent i gjenbruk, kopiering, plagiering, stjeling og identitetstyveri, og belønnet for å vise det motsatte av originalitet. Metodene ble utforsket i et åpent trygt miljø. Eksempler på arbeid fra kurset var avskrift fra dokumenter, transkriberte lydklipp eller komma-endringer i sider fra Wikipedia. På eksamen skulle studentene kjøpe en ferdig skrevet oppgave fra et online-arkiv, signere med sitt eget navn, og presentere og forsvare oppgaven foran klassen, som om det var deres egen.

Problemstillingene i dette eksempelet handler om hvilke valg studentene gjør når de plukker ut en tekst, om de velger en tekst som representerer deres syn i en sak eller motsatt, og om det er mulig å forsvare noe de ikke selv har skrevet. Å velge noe gjør at man samtidig velger bort noe. Goldsmiths argument er at vi aldri har lært å verdsette slike valg: "the suppression of self-expression is impossible» (2011, s. 9). På lignende måte argumenterte Bourriaud for at Marcel Duchamp endret hva en kreativ prosess må bestå av. Gjennom å stille ut pre-produserte gjenstander som åndsverk ble handlingen å velge nok til å konstituere en kunstnerisk prosess (Bourriaud, 2005, s. 25).

Larsens og Goldsmiths undervisningsopplegg utfordrer elevers og studenters holdning til originalitet, og jeg har brukt begge som grunnlag i utvikling av undervisningsopplegget i denne studien. Fra det første eksempelet er det relevant hvordan oppgaven blir gitt som en utfordring til elevene, og hvordan dette viser seg i refleksjonene. Det andre eksempelet presser grensen mer mot en ulovlig handling, hvor studentene blir bedt om å utføre det kanskje minst akseptable i hele akademia. I prosessen oppstår det en vridning av perspektivet på originalitet som jeg anvender i min studie. Ved å ta en motsatt tilnærming til originalitet kan man ifølge Goldsmith finne et annet uttrykk for personlighet, som er umulig å undertrykke (2011).

I min casestudie er det nettopp denne vridningen av perspektivet som er grunnlaget for undervisningen. Studentene har ikke jobbet fritt med bildeskaping og fulgt sine vanlige impulser. Jeg kommer tilbake til hvordan de har utforsket strategiene bak 
Silje Bergman. Kopiering og kulturelle referanser som verktøy i bildeskaping

appropriasjon og re-mediering. Det innebar blant annet spørsmål om hva som kreves for å være original og hva som kunne forsvares med ytringsfrihet. Valg av verk og grad av kopiering har vært åpent, mens utvikling av studentenes interpikturelle litterasitet har ligget som premiss for å løse oppgavene i undervisningsopplegget.

\section{Forskningsmetode}

For å undersøke problemstillingene utviklet jeg et undervisningsopplegg for faglærerstudenter i design, kunst og håndverk, der jeg både underviste og observerte. Det empiriske materialet besto av visuelle arbeider og skriftlige refleksjoner fra studenter, i tillegg til observasjonsnotater fra undervisnings- og veiledningsøkter.

Materialet ble analysert som kvalitativt case (Yin, 2009). Jeg har undersøkt data fra flere kilder og ulike studentkull og tidsrom for dypere innsikt og for triangulering, som $ø k e r$ studiens reliabilitet. Studien er eksplorativ med en åpen tilnærming til materialet, og jeg har brukt fremgangsmåter fra Visual Methods (Banks, 2007) og Grounded Theory (Corbin \& Strauss, 2015).

\section{Informanter}

Informantene i denne studien er studenter fra en faglærerutdanning i design, kunst og håndverk ved et universitet i Norge, og undersøkelsene er gjennomført med tre årskull i forskjellige studieår. Alle informantene har vært i første år av sin faglærerutdanning. Til sammen har 54 informanter deltatt i studien. Ytterligere 13 studenter har fulgt undervisningen, men reservert seg mot datainnsamlingen.

Informanter og undervisningsformer er valgt etter bestemte kriterier: Studentgrupper med spenn i alder og utdanningsbakgrunn ble valgt for å fange opp om grunnutdanningen har hatt et annet fokus på opphavsrett de senere årene. Faglærerutdanningen i design, kunst og håndverk ble valgt fordi informanter herfra relativt nylig har hatt erfaring med det norske utdanningssystemet innenfor kunst- og håndverksfag, med både læreplanens kompetansekrav og praktiserte nivå. Utvalget er ingen homogen gruppe, men inneholder både yngre og eldre informanter, og deres ulike i pedagogiske bakgrunn gir flere nyanser til datamaterialet. Utvalget har et lavt antall mannlige studenter, noe som speiler kjønnssammensetningen i faglærerutdanningene i design, kunst og håndverk. Datamaterialet som vises til i denne artikkelen er visuelle og skriftlige ytringer som er representative for flertallet av informantene. De representerer likhetstrekk, men også spennet i informantenes 
Silje Bergman. Kopiering og kulturelle referanser som verktøy i bildeskaping

erfaringer og refleksjoner. I det videre refererer jeg til informantene i denne casestudien som studenter.

\section{Forskerrollen}

Forskerrollen i denne studien var todelt: jeg var både forsker og lærer. Jeg utviklet undervisningsmaterialet som skulle møte bestemte kompetansemål i studentenes utdanningsplan. Jeg var også deltakende observatør i klasserommet og undersøkte studentenes handlinger innenfor en bestemt kontekst.

Innenfraperspektivet til det empiriske materialet skapte spesielle utfordringer. Ved feltarbeid i egen praksis var jeg bærer av den samme kulturen som jeg undersøkte (Wadel, 1991, s. 18-21), og jeg hadde en forforståelse av fagfeltet som kunne komme i konflikt med forskerrollens analytiske distanse (Wadel \& Fuglestad, 2014, s. 225). «Forskerens begrepsapparat kan være med på å avhjelpe slik «hjemmeblindhet» (...) En fordel med studier på «hjemmebane» vil være nærhet og kjennskap til feltet, som kan gi lettere kunnskapstilgang» (Mikkelsen \& Rist, 2018, s. 169). I rollen som forsker hadde jeg ambisjoner om å møte empirien med objektivitet, men også med et deltakerperspektiv og en innenfraposisjon som kunne gi forståelse av fenomenet fra flere vinkler. Som deltagende observatør i egen kultur hadde jeg påvirkning på det jeg undersøkte. Det er en etablert forståelse at studier med deltagende observatører kan bidra til «forskningseffekt» (Tjora, 2017, s. 71). Jeg var forskeren, men også læreren som satte karakterene. Tidligere forskning viser at slik påvirkning vanskelig kan unngås når man forsker på egne studenter (Brænne, 2009; Gulliksen, 2009). Imidlertid kunne virkningen reduseres ved at jeg observerte over tid, og at samme type situasjoner ble skapt flere ganger med ulike studentgrupper (Wadel, 1991, s. 21). I situasjonene vekslet jeg mellom forskerperspektiv og lærerperspektiv, og etter observasjonene var det jeg som fortolket, tok valg og gjorde eventuelle endringer i undervisningsopplegget.

\section{Undervisningsopplegget}

Oppstart av hver undervisningsperiode bestod av studentaktive forelesninger om ulike kunstformer og strategier som re-medierer eksisterende verk. Disse ble drøftet i lys av sentrale paragrafer og forarbeider til åndsverkloven som studenter har fri tilgang til gjennom Rettsdata og Lovdata Pro. Diskusjonene som oppstod førte med seg relevante refleksjoner om rettigheter, lånekultur, delingskulturer, bildelisenser og avtaler for bruk i skolen. Temaer som ble løftet frem handlet i stor grad om hva som er lov til å gjøre med bilder i skolesammenheng sammenlignet med i sosiale medier, og hvor skillet går mellom privat sfære og det offentlige rom. Det kanskje oftest stilte 
Silje Bergman. Kopiering og kulturelle referanser som verktøy i bildeskaping

spørsmålet fra studentene var hvordan vederlagsordningene fungerer, og hvordan den økonomiske støtten går tilbake til skaperne av de verk som lærere bruker i undervisningen. Store deler av det vederlaget Kopinor krever inn, fordeles kollektivt i form av for eksempel stipendtildelinger til både medlemmer og ikke-medlemmer (Smith-Meyer, 2020). Selv om åndsverkloven regulerer det juridiske rundt opphavsrett, og i stor grad beskytter opphaveres og eieres økonomiske interesser, var fokus i denne undervisningen først og fremst beskyttelse av de ideelle rettighetene -som belønning av åndelig kreativitet og insentiv til kulturell produksjon (Åndsverkloven, 2018 §5). Samtidig ble informasjons- og ytringsfriheten vektlagt med eksempler på hvordan åndsverkloven også har regler som begrenser omfanget av opphavsretten (Åndsverkloven, 2018 kap.3). Mange studenter hadde egne erfaringer med deling av bilder, strikkeoppskrifter og annet håndverk i sosiale medier som var gode eksempler til diskusjon. Forelesningene inneholdt også viktige redegjørelser av strategiene bak for eksempel appropriasjon, remiks, mash-up og fan art, men ansporet også til reflekterende diskusjoner omkring etikk, teknikk og estetikk. Blant annet i hvilken grad egenutviklede teknikker kan være avgjørende for et verks estetiske uttrykk, og om det av den grunn vil være beskyttet av åndsverkloven. Et annet tema som engasjerte var hvilken betydning statusen til den som kopierer har for om kopiering blir sett som en krenkende handling.

Undervisningen var utviklet som en læringsdialog: jeg presenterte ulike problemstillinger og eksempler på arbeider som krysset grensen for plagiat, og caser som gjerne var utfordrende i et opphavsrettsperspektiv. Studentene gikk analytisk inn i problemstillingene, diskuterte og reflekterte ofte egne erfaringer med eksempler fra egen livsverden. Jensen og Leirviks definisjon av læringsdialog rommer at elever deltar aktivt med egen forståelse av lærestoffet, og at deres bidrag til samtalen utvikler en dypere og mer helhetlig kunnskap (Jensen \& Leirvik, 2015, s. 28). Studentene i denne studien skal selv skal bli lærere, og dermed får læringsdialogen en dobbelt rolle. I tillegg til å utvikle studentenes egen forståelse av lærestoffet erfarte de hvordan eget bidrag til kunnskapsutviklingen har betydning, og de så hvordan læringsdialogen kan tas i bruk for å bygge undervisning på elevers historier fra egen livsverden.

Etter introduksjonen der opphavsrett ble drøftet gjennom konkrete eksempler og teoretiske problemstillinger, ble den skapende delen startet med praktisk innføring i bildebehandling med digitale verktøy. Opplæringen bestod av praktiske øvelser i Photoshop, som bildekorreksjon, redigering, manipulasjon, digital tegning osv., som 
Silje Bergman. Kopiering og kulturelle referanser som verktøy i bildeskaping

gikk over i en friere oppgave der studentene skulle skape et eget visuelt verk, men hvor premisset var at de måtte ta utgangspunkt i et eller flere eksisterende kunstverk.

Prosessen var delt i tre faser, hvorav den første, konstruksjon, handlet om at studentene skulle orientere seg om bakgrunn, innhold og symbolikk i eksisterende kunstverk de ville bruke som forelegg. I den neste fasen, dekonstruksjon, skulle studentene identifisere ulike elementer i verkene og løse disse opp, både visuelt og innholdsmessig. Den tredje fasen, rekonstruksjon, var starten på en selvstendig skapende prosess. Her var målet å finne en egen stemme, uttrykke seg selv gjennom det som var valgt ut (kopiert), bruke det som inspirasjonen og manipulere elementer på ulike måter. Alle fasene utfordret studentenes kritiske refleksjon, etiske vurderinger og tekniske ferdigheter på ulike måter.

\section{Casestudiens empiri}

Hver studentgruppe har mottatt ca. 18 undervisningsøkter, fordelt på forelesning om opphavsrettslige problemstillinger, opplæring i digitale verktøy, øvelser og skapende arbeid. Tabellene nedenfor viser en oversikt over ulike former for data som ble samlet inn i studien. Det visuelle datamaterialet er delt i øvingsoppgaver og bildeskaping. Øvingsoppgavene var teknisk ferdighetstrening for å kunne manipulere bilder med digital programvare. Bildeskaping representerer resultatene fra de tre fasene: konstruksjon, dekonstruksjon og rekonstruksjon. Det skriftlige datamaterialet består av studentenes individuelle refleksjoner og argumentasjoner knyttet til arbeidsmetoden. Her var det vesentlig å finne studentenes forståelse av hvordan reglene i åndsverkloven griper inn i deres bruk av kunstverkene. Mine feltlogger ble skrevet straks etter hver økt. I tillegg til observasjoner dekket de problemstillinger som ble diskutert i de ulike øktene for å dokumentere hva slags kunnskapsgrunnlag studentene reflekterte ut ifra. 
Silje Bergman. Kopiering og kulturelle referanser som verktøy i bildeskaping

\begin{tabular}{|c|c|c|c|c|c|c|c|c|c|c|c|}
\hline \multicolumn{4}{|l|}{ Del 1} & \multicolumn{4}{|l|}{ Del 2} & \multicolumn{4}{|l|}{ Del 3} \\
\hline \multicolumn{2}{|c|}{$\begin{array}{l}\text { Data fra undervisning, } \\
\text { studentarbeid }\end{array}$} & \multicolumn{2}{|c|}{$\begin{array}{l}\text { Observasjons- } \\
\text { data }\end{array}$} & \multicolumn{2}{|c|}{$\begin{array}{l}\text { Data fra undervisning, } \\
\text { studentarbeid }\end{array}$} & \multicolumn{2}{|c|}{$\begin{array}{l}\text { Observasjons- } \\
\text { data }\end{array}$} & \multicolumn{2}{|c|}{$\begin{array}{l}\text { Data fra undervisning, } \\
\text { studentarbeid }\end{array}$} & \multicolumn{2}{|c|}{$\begin{array}{l}\text { Observasjons } \\
\text { data }\end{array}$} \\
\hline \multicolumn{2}{|c|}{ Visuelt datamateriale } & \multicolumn{2}{|c|}{$\begin{array}{l}\text { Feltlogg fra } \\
\text { undervisning }\end{array}$} & \multicolumn{2}{|c|}{ Visuelt datamateriale } & \multicolumn{2}{|c|}{$\begin{array}{l}\text { Feltlogg fra } \\
\text { undervisning }\end{array}$} & \multicolumn{2}{|c|}{ Visuelt datamateriale } & \multicolumn{2}{|c|}{$\begin{array}{l}\text { Feltlogg fra } \\
\text { undervisng }\end{array}$} \\
\hline $\begin{array}{l}\text { Øvings- } \\
\text { oppgaver }\end{array}$ & $\begin{array}{l}\text { Bilde- } \\
\text { skaping }\end{array}$ & $\varnothing$ kter & Sider & $\begin{array}{l}\varnothing \text { ving- } \\
\text { soppgaver }\end{array}$ & $\begin{array}{l}\begin{array}{l}\text { Bilde- } \\
\text { skaping }\end{array} \\
\end{array}$ & $\varnothing \mathrm{kter}$ & Sider & $\begin{array}{l}\text { Øvings- } \\
\text { oppgaver }\end{array}$ & $\begin{array}{l}\begin{array}{l}\text { Bilde- } \\
\text { skaping }\end{array} \\
\end{array}$ & $\varnothing$ kter & Sider \\
\hline 11 & 2 & 19 & 12 & 13 & 2 & 17 & 15 & 14 & 2 & 17 & 16 \\
\hline Besvarelser & $\begin{array}{l}\text { Student- } \\
\text { arbeider }\end{array}$ & & & Besvarelser & $\begin{array}{l}\text { Student- } \\
\text { arbeider }\end{array}$ & & & Besvarelser & $\begin{array}{l}\text { Student- } \\
\text { arbeider }\end{array}$ & & \\
\hline 209 & 29 & & & 325 & 53 & & & 140 & 20 & & \\
\hline \multicolumn{2}{|c|}{ Skriftlig datamateriale } & \multicolumn{2}{|c|}{$\begin{array}{l}\text { Feltlogg fra } \\
\text { veiledning }\end{array}$} & \multicolumn{2}{|c|}{ Skriftlig datamateriale } & \multicolumn{2}{|c|}{$\begin{array}{l}\text { Feltlogg fra } \\
\text { veiledning }\end{array}$} & \multicolumn{2}{|c|}{ Skriftlig datamateriale } & \multicolumn{2}{|c|}{$\begin{array}{l}\text { Feltlogg fra } \\
\text { veiledning }\end{array}$} \\
\hline $\begin{array}{l}\text { Refleksjons- } \\
\text { oppgaver }\end{array}$ & $\begin{array}{l}\text { Refleksjons- } \\
\text { tekst }\end{array}$ & $\varnothing$ kter & Sider & $\begin{array}{l}\text { Refleksjons- } \\
\text { oppgaver }\end{array}$ & $\begin{array}{l}\text { Refleksjon } \\
\text { s-tekst }\end{array}$ & $\varnothing \mathrm{kter}$ & Sider & $\begin{array}{l}\text { Refleksjons- } \\
\text { oppgaver }\end{array}$ & $\begin{array}{l}\text { Refleksjons- } \\
\text { tekst }\end{array}$ & $\varnothing$ kter & Sider \\
\hline 1 & 19 & 1 & 30 & 2 & 50 & 6 & 35 & 2 & 20 & 13 & 44 \\
\hline
\end{tabular}

Figur 1. Tabeller over datamateriale fra de tre delstudiene

\section{Utvikling av kategorier}

Datamaterialet fra casestudien har blitt tematisert og kategorisert for å skape oversiktlighet, og for å lokalisere resultater som hadde fellestrekk (Corbin \& Strauss, 2015; Postholm, 2010). De visuelle studentarbeidene har tjent som grunnlag for å utvikle et analysesystem for interpikturelle egenskaper i bildeskaping, og alle studentenes bilder har siden blitt analysert gjennom dette systemet.

Fremgangsmåten ble valgt etter en innledende tematisk analyse av både skriftlige og visuelle data fra den første delstudien. Noen tydelige temaer og begreper kom frem da jeg søkte i datamaterialet etter svar på: hva slags verk som var valgt som forelegg, på hvilken måte verkene var bearbeidet eller sammensatt, hvordan verkets mening ble endret, og hvilke formalestetiske virkemidler som ble brukt. Temaene ble definert i noen bestemte kategorier for å strukturere og gjøre et komplekst materiale mer håndterbart (Johannessen, 2018). Den tematiske analysen resulterte i 6 kategorier som definerte ulike interpikturelle egenskaper i skapende prosesser. Disse 6 kategoriene kan brukes for å analysere og vurdere studentarbeider, og de kan brukes som faglig verktøy i undervisning for å markere mulighetene til å behandle eksisterende verk i skapende prosesser.

De 6 kategoriene har fått betegnelsene Mash-up, Parodi, Bearbeidelse, Homage, Referanse og Inspirasjon. Hver kategori defineres ganske kort i denne artikkelen, men de er utpreget visuelle og eksemplifiseres derfor visuelt med studentarbeider direkte under hver kategoribeskrivelse. Bildeeksemplene representerer en 
Silje Bergman. Kopiering og kulturelle referanser som verktøy i bildeskaping

interpikturell bruk av eksisterende verk innenfor den enkelte kategori.

Problemstillinger knyttet til opphavsrett, bildebruk og til studentenes refleksjoner over egen skapende prosess løftes også frem og drøftes under bildene.

I beskrivelsene av kategoriene har det vært hensiktsmessig å trekke inn begreper fra litteratur-, film- og musikkverdenen i tillegg til kunstverdenen. Begrepene er overførbare til en visuell kontekst selv om de ikke beskriver nøyaktig samme fenomen. For eksempel kan det å bruke begrep fra musikkfeltet, på visuelle uttrykk, skape assosiasjoner og legge et ekstra lag av mening til verket. Referansen til musikk er med på å farge tolkningen av det visuelle uttrykket. Dette gjelder også for hvordan jeg har brukt perspektiver fra litteraturfeltet, for eksempel Uncreative Writing (Goldsmith, 2011), både i utvikling av kategorier og i utforskning av undervisningsmetoder.

\section{Diskusjon av resultater}

I det følgende presenteres kategoriene, sammen med to eksempler på studentarbeider fra hver kategori. Studentarbeider som vises her, er klarert med studentene (opphavere) for bruk i denne artikkelen, publisert på Internett, men arbeidene kan ikke brukes i andre sammenhenger uten samtykke fra opphavere. Studentene er anonymisert med pseudonym A, B, C osv. iht. regler for publisering av forskningsdata. Undersøkelsen er registrert hos Norsk senter for forskningsdata (NSD, 2017).

Studentenes arbeider og refleksjoner over den konkrete behandlingen av opphavsrettsbeskyttede verk, diskuteres med utgangspunkt i de to problemstillingene. 1) Hvordan kan kopiering og kulturelle referanser brukes som interpikturelle verktøy i studenters bildeskaping? 2) Hvordan kan studenter utvikle evne til å gjøre opphavsrettslige vurderinger gjennom å reflektere over egne interpikturelle prosesser?

\section{Kategori 1 - Mash-up}

Mash-up begrepet er mest brukt innenfor musikkfeltet. Som musikksjanger leker mash-up kreativt med sammenstilling av verk, vanligvis to eller flere forhåndsinnspilte sanger. Begrepet brukes stadig oftere i andre kunstformer og kan mer generelt forklares som sammenveving av biter fra forskjellige kilder (Bergman, 2019; Lamb, 2007; Rostama, 2015). Mash-up representerer i denne studien bearbeidelser der deler av verk fra ulike kunstnere og tider blir satt sammen til en ny visuell helhet, men ikke nødvendigvis til et nytt budskap. Hvis det nye visuelle uttrykket overdøver de 
Silje Bergman. Kopiering og kulturelle referanser som verktøy i bildeskaping

anvendte verkenes visuelle uttrykk, kan dette ha betydning for vurdering av hvor nyskapende arbeidet er. Studentarbeidene som er plassert i denne kategorien, bygger gjerne videre på historien fra de originale verkene, men hvorvidt budskapet er endret har ikke vært avgjørende for kategorien.

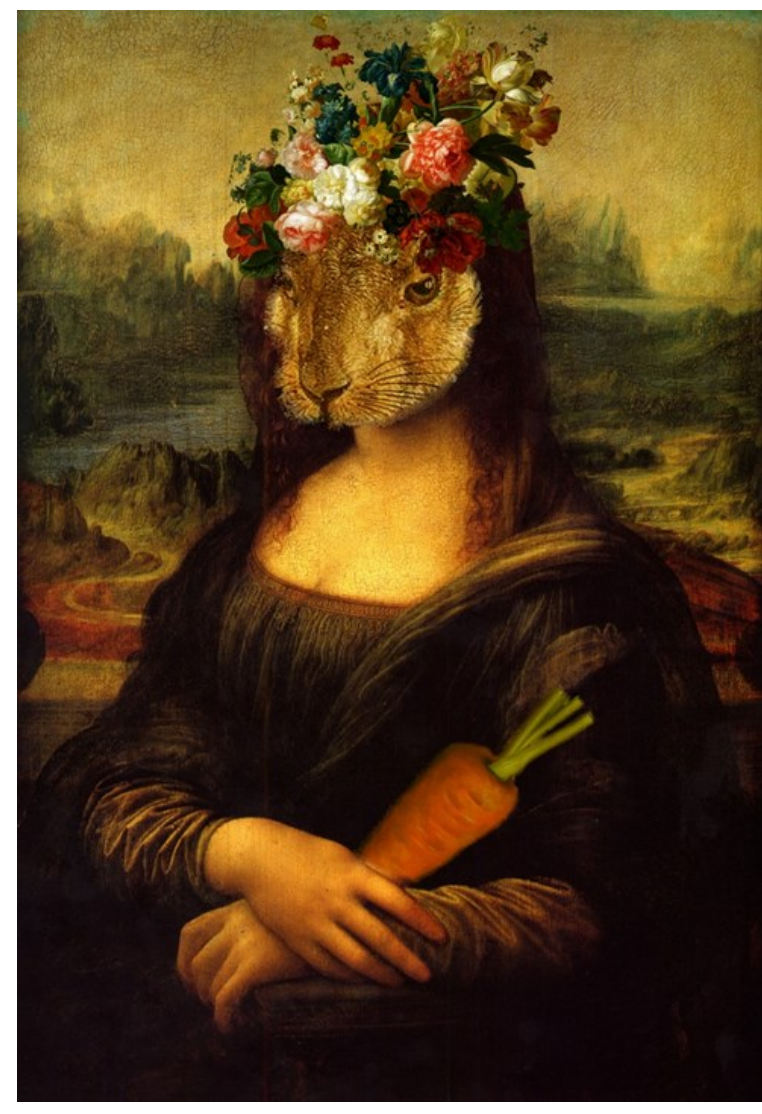

Figur 2. Student A. Mash-up av Mona Lisa, Leonardo da Vinci (1519), Feldhase, Albrech Dürer (1502) Jan van Huysums Flowers in a Terracotta Vase (1736) og A Carrot, Faith Te (2010). CC BY-NC-ND 4.0

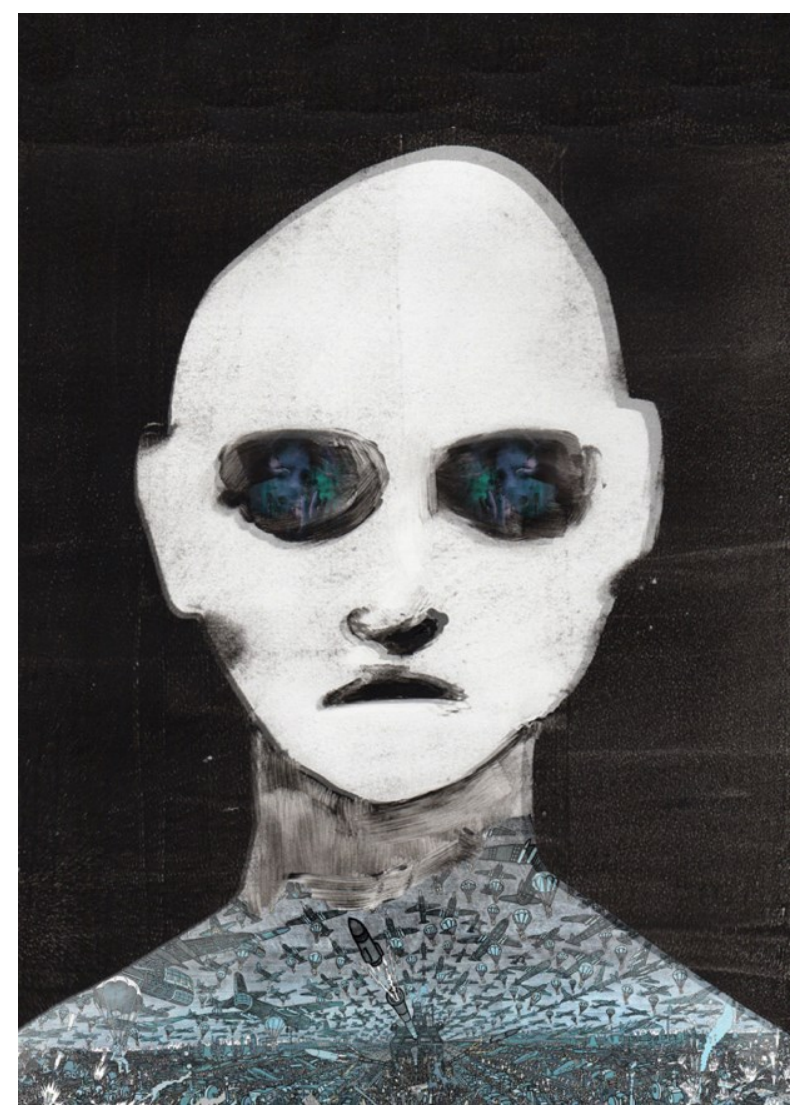

Figur 3. Student B. Mash-up av Revenant III, Cathrine Liberg og Jobkill, Hariton Pushwagner (1990). CC BY-NC-ND 4.0

Student $A$ (figur 2): Jeg valgte å kun bruke malerier, fordi at overflatene skulle være nogenlunne like. Jeg har redigert fargene, på maleriene for å gli bedre inn i det valgte bakgrunnsbildet, Det er helt klart at de er redigert og skiller seg helt klart ut fra de orginale bildene, men mener likevel selv at bildene ikke er redigert nok til å kunne kalles et eget og selvstendig verk. Vi ser godt at bildet er av Mona Lisa, selv om ansiktet er tydelig byttet ut med en kanin.

Student B (figur 3): Ifølge åndsverkloven har man rett på beskyttelse av det man har skapt og sier også at verket man har skapt er beskyttet i 70 
Silje Bergman. Kopiering og kulturelle referanser som verktøy i bildeskaping

år etter at opphavsmannens død. Jeg mener derfor at ettersom man kan gjenkjenne både verket til Cathrine Liberg og Pushwagner i form og farge er ikke dette noe jeg kan si er mitt selvstendig verk.

I kategorien mash-up har verkene, som opprinnelig er bærere av en type symbolikk og kulturelt innhold, blitt satt inn i nye sammenhenger. Felles for arbeidene i denne kategorien er at studentene har hentet elementer fra kjente verk og flettet disse sammen til en ny visuell helhet. Studentarbeidene forteller andre historier, men refererer samtidig til noe vi kjenner igjen. Eksempler på dette er manipulasjon av lys og fargetoner i figur 2, som skaper sømløse og overganger mellom de ulike elementene studenten har hentet fra foreleggene. Uttrykket kan assosieres med da Vincis maleriske teknikk «sfumato», som gir de typiske utviskede konturene. Maleriet av en gulrot er lisensiert under Creative Commons-lisensen CC BY-NC 4.0, øvrige verk er falt i det fri.

I figur 3 har Libergs gjenganger fått et vindu inn i Pushwagners brutale krigsskildring. Sammenkoblingen av motivene, i studentens Mash-up, gjør at originalenes dystopiske symbolikk forsterkes og utvikles. Til forskjell fra de fleste bildene som er brukt i figur 2, har ikke de kopierte bildene i figur 3 falt i det fri. Libergs estetiske uttrykk er fremdeles sterkt til stede i det nye arbeidet, noe som gjør det vanskelig å argumentere for at dette etter loven er en bearbeidelse som ikke er avhengig av opphavsretten til de originale verkene. På den annen side refererer figur 3 til Libergs utforskning av grafikk lag på lag, der fragmenter kan representere større nasjonale og globale historier.

\section{Kategori 2 - Parodi}

Parodi er i tradisjonell forstand en etterligning av et kjent kunstverk, ofte diktning, med et ironisk tilsnitt. Det kan også brukes om karikaturer eller et vrengt bilde av en person. Parodi er knyttet til ytringsfrihet, og er et ulovfestet unntak fra opphavsretten (Aakre, 2002, s. 86-92; Rognstad \& Lassen, 2009, s. 144, 145). I praksis åpnes det for et større mulighetsrom når kopiering gjøres i en parodisk form. Parodi representerer i denne studien arbeider som leker med manipulasjoner av kunstverk og kombinasjoner av flere verk, med en tydelig ironisk vri. Poenget er gjerne satt på spissen, med vrengte versjoner av originalenes budskap. 


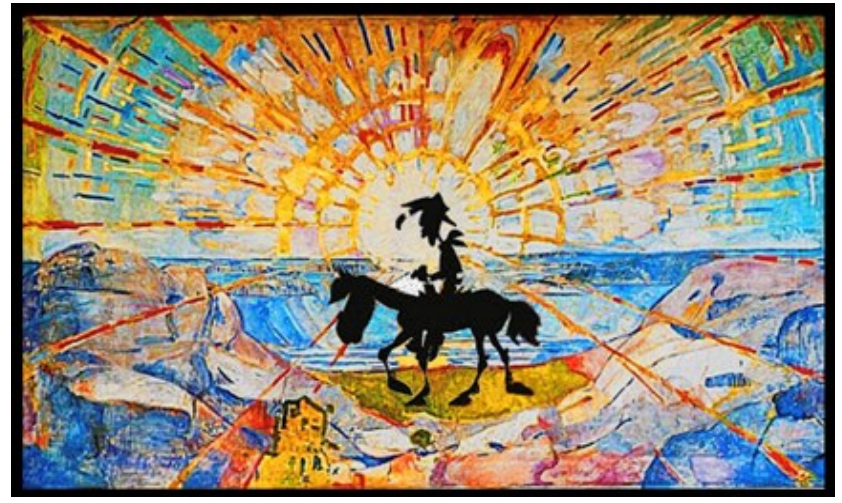

Figur 4. Student C. Parodi på Lucky Luke, Morris De Bevere og Solen, Edvard Munch (1916). CC BY-NC-ND 4.0

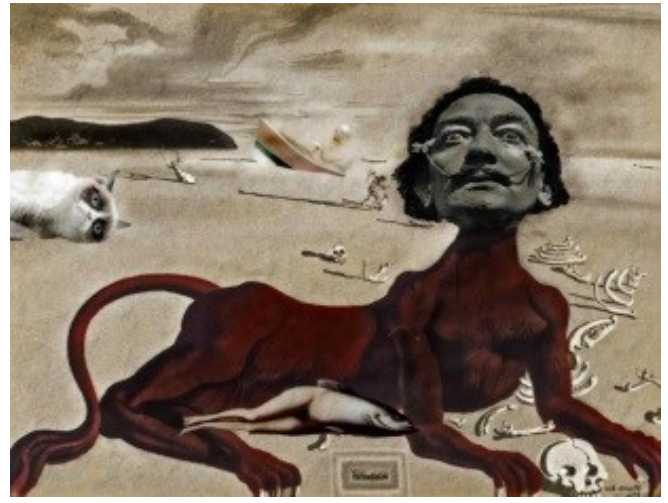

Figur 5. Student D. Parodi på Shirley Temple, The Younest, Most Sacred Monster of the Cinema in Her Time, Salvador Dalí (1939) og The collective invention, Rene Magritte (1934).

CC BY-NC-ND 4.0

Student C (figur 4): Skaperen av Lucky Luke døde i 2001, og bildene er beskyttet av åndsverksloven. Her ville det vært helt nødvendig å sjekke ut nasjonal og internasjonal åndsverkslov og regler for opphavsrett, om mitt bilde skulle publiseres for eksempel på sosiale media, bloggside, eller annen bruk. Men om dette skulle bli brukt i undervisningssammenheng ville det ifølge Kopinors avtale kunne brukes, eller som en oppgave som elevene ikke kan publisere. Sammen med Munchs Solen settes bildene i en ny vri, og gir kunstverkene en ny kontekst, nemlig i en mer komisk og kommersiell retning.

Student $D$ (figur 5): Bildet er ikke likt som det opprinnelige, men om det er veldig nyskapende det vet jeg ikke. Dalis bilde var veldig «random», jeg fortsatte i samme stil med å lime inn deler fra andre bilder for å vise en annen side. Jeg satte inn hodet til Salvador Dalí og en fisk fra Margitte som skal symbolisere Dalís barn i en surrealistisk verden.

I kategorien parodi tar eksemplene utgangspunkt i foreleggene, men med en visuell og innholdsmessig vri. Studentene har lekt med ulike temaer. Figur 4 er en humoristisk vinkling på kitsh-temaet «elg i solnedgang» med tegneseriekarakteren Lucky Luke manipulert inn i Munchs soloppgang over Kragerøs skjærgård, som om han rider inn i sol-nedgangen.

Kombinasjoner av elementer fra flere forskjellige verk var også brukt for å spisse et tema. Eksempel på dette er figur 5 hvor en meta-parodi harselerer med Dalís ofte eksentriske uttrykk. Originalverket var en satirisk kritikk mot seksualiseringen av 
Silje Bergman. Kopiering og kulturelle referanser som verktøy i bildeskaping

Hollywoods barnestjerner. Studenten har manipulert blant annet Dalís portrett og en havfrue fra et av Magrittes verk, opprinnelig en parodi på den tradisjonelle havfruen. Her parodieres både parodiererne, og surrealismen som sjanger. Det at arbeidene ironiserer over kunst, kunstnere og det opprinnelige temaet kan ha betydning for om de vil falle inn under ytringsfriheten, og i så tilfelle vurderes som parodi i opphavsrettssammenheng.

\section{Kategori 3 - Bearbeidelse}

Bearbeide/se kan defineres vidt som å arbeide videre med noe, eller tilpasse det til en annen form. I kunst brukes det gjerne om oversettelser, musikkarrangementer, filmatiseringer av romaner eller nyoppsetningen av kjente teaterstykker. Innenfor opphavsrett er bearbeidelse et definert begrep som forteller at noen skaper en ny versjon ut ifra et eldre åndsverk. Den nye utformingen skal fremtre som resultat av en skapende åndsinnsats (Bergman, 2019; Åndsverkloven, 2018 §6). Viktige elementer i verket er ofte byttet ut eller redigert, slik at et nytt visuelt uttrykk skiller det fra forelegget. Budskapet kan være endret, men hovedfokus er den visuelle endringen.

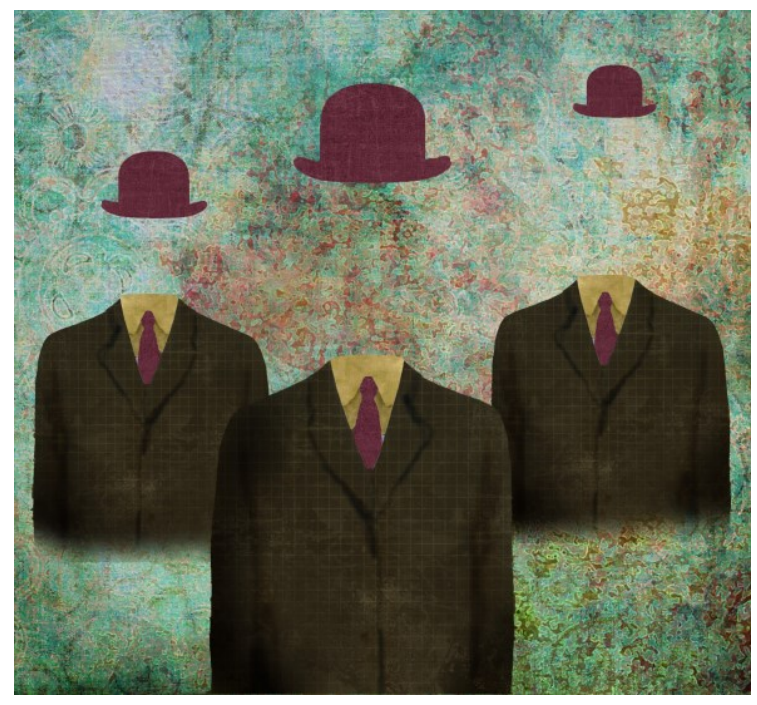

Figur 6. Student E. Bearbeidelse av Rene Magritte, The Pilgrim (1966). CC BY-NC-ND 4.0

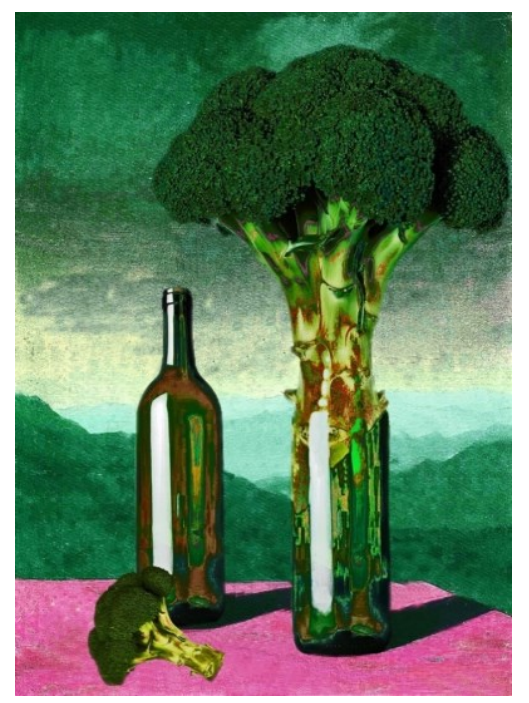

Figur 7. Student F. Bearbeidelse av Rene Magritte, The Explanation (1952). CC BY-NC-ND 4.0

Student $E$ (figur 6): Elementene jeg har kopiert fra Rene Magritte er redigert og forandret, men hvis jeg skulle lagt det ut på nett ville jeg referert til Magritte bare for å være på den sikre siden. Jeg ville i hvert fall tatt med at jeg har hentet inspirasjon derfra.

Student $F$ (figur 7): Bildet er en etterligning, en sitering av The Explanation. I følge åndverksloven har jeg egentlig ikke lov å bruke 
materialet på grunn av 70 års-regelen. Om det er nytt og selvstendig kan være avhengig av hvem jeg spør.

I kategorien bearbeidelse har studentene byttet ut og bearbeidet elementer for å skille det fra forelegget. Både figur 6 og 7 er tydelige bearbeidelser av Magrittes verk og den surrealistiske sjanger, å bytte gulrot mot brokkoli endrer ikke på det. Det er vanskelig å argumentere for at disse to eksemplene er tilstrekkelig nyskapende, og vil kunne vurderes som for lite selvstendige hvis de skulle offentliggjøres.

\section{Kategori 4 - Homage}

Homage er en hyllest til kunstverk eller kunstner (Hubbard, 2003). Betegnelsen ble mye brukt om imitasjon i postmodernistisk kunst på 90-tallet, da spesielt i filmens verden. En homage kan kopiere kjente deler av et originalverk som alle vil dra kjensel på, men kan også hylle sin inspirasjonskilde gjennom en nesten umerkelig detalj, hvor bare noen få vil se sammenhengen. Ofte vil en homage ligne parodi med en humoristisk vri på verket den hyller. Homage i denne studien stiller ikke krav til humor, men er en visuell hyllest til en kunstner eller kunstverk.

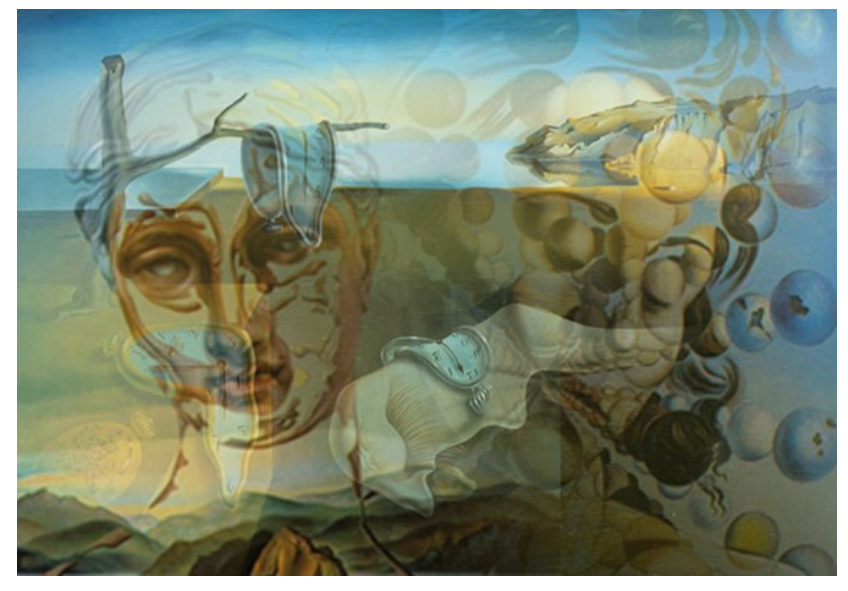

Figur 8. Student G. Homage til Salvador Dalí, The Persistence of Memory (1931), Galatea of the Spheres (1952) og Birth of a Divinity (1960). CC BY-NC-ND 4.0

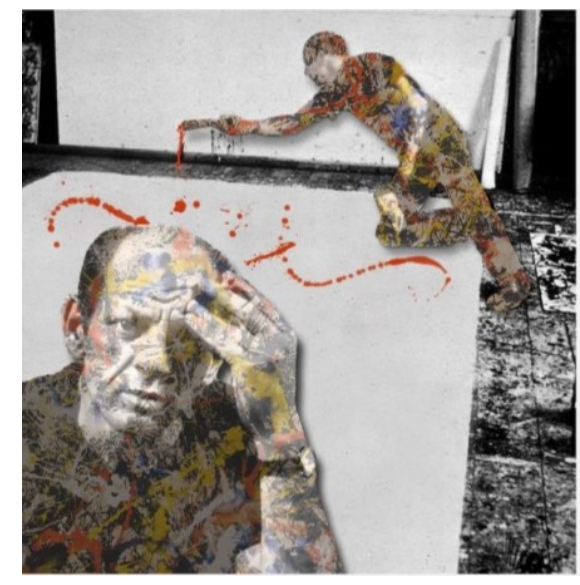

Figur 9. Student H. Homage til Jackson Pollock, Convergance (1952), fotografi David Lefranc/Corbis Kipa og Hans Namuth (1950). CC BY-NC-ND 4.0

Student $G$ (figur 8): Bildene ble satt opp imot hverandre slik at helheten skulle vise til to forskjellige verdener eller å vise til to måter Dali uttrykte seg på i malerier. Jeg har laget et nytt bilde som henviser til en ny historie, og mener at dette bildet kan bli sett på som et nyskapende arbeid i den forstand at jeg har klart å videreutvikle et bilde med to andre bilder. 
Silje Bergman. Kopiering og kulturelle referanser som verktøy i bildeskaping

Student $H$ (figur 9): Både verket til Pollock og fotografiene av han har verkshøyde og det er ikke mer enn 70 år siden Pollock eller disse fotografene gikk bort. Disse verkene er fortsatt beskyttet av åndsverksloven. Jeg kan derfor ikke lovlig publisere dette bilde offentlig. Jeg føler at bildet som helhet bærer lite preg av mitt eget uttrykk. Vitsen med å lage en homage er jo at den hyllede kunstnerens uttrykk kommer frem og med det tatt i betraktning blir mulighetene mindre for å legge mye av eget uttrykk in i verket.

I kategorien homage har studentene på ulike måter hyllet et kunstnerskap ved for eksempel å sammenstille flere verk eller elementer til en ny helhet. De to eksemplene her viser i ulik grad selvstendighet og nyskapende elementer. $\AA$ kombinere ulike verk sammen til en ny helhet er ikke nødvendigvis nyskapende uten at det bindende leddet er skaperens (studentens) eget bidrag til den nye historien. Figur 8 er en kombinasjon av flere verk av Dalí, mens figur 9 er et helt nytt motiv, skapt av studenten ved å binde sammen Pollocks verk og portretter av Pollock. Studenten hyller abstrakt ekspresjonisme og visualiserer et sitat av Pollock, ved å illustrere hvordan han legger de følelsene han har på innsiden, ut over lerretet: «My concern is with the rhythms of nature. ... I work inside out, like nature» (Emmerling, 2003, s. 48).

I praksis vil ofte en homage til kunstner eller kunstverk tillates, selv om åndsverkloven ikke har et eget unntak for dette. I tillegg til opphavsrett kan denne bruken berøre både personvernloven med retten til eget bilde når det er et gjenkjennelig portrett (Wessel-Aas, 2016, s. 65), samt opphavsretten til fotografen som har tatt portrettbildene. I dette tilfellet er Pollock død for over 60 år siden og personvernet gjelder til og med 15 år etter utløpet av avbildedes dødsår. Fotografens opphavsrett må likevel vurderes knyttet til denne bruken.

\section{Kategori 5 - Referanse}

Referanse brukes vanligvis om henvisning i tekst. I denne studien har det likhetstrekk med homage ved at en referanse snakker med andre verk og kunstnere gjennom imiterende detaljer (Bergman, 2019, s. 11,18). Men kategorien skiller seg fra forrige ved at det ikke er en hyllest. Det som kopieres kan ha mindre betydning enn det nye som oppstår. Det kan være små elementer som peker til noe vi kjenner igjen fra for eksempel kunsthistorien. Slike elementer kan også være en kunstners karakteristiske penselstrøk, eller typisk fargebruk fra en bestemt epoke. 


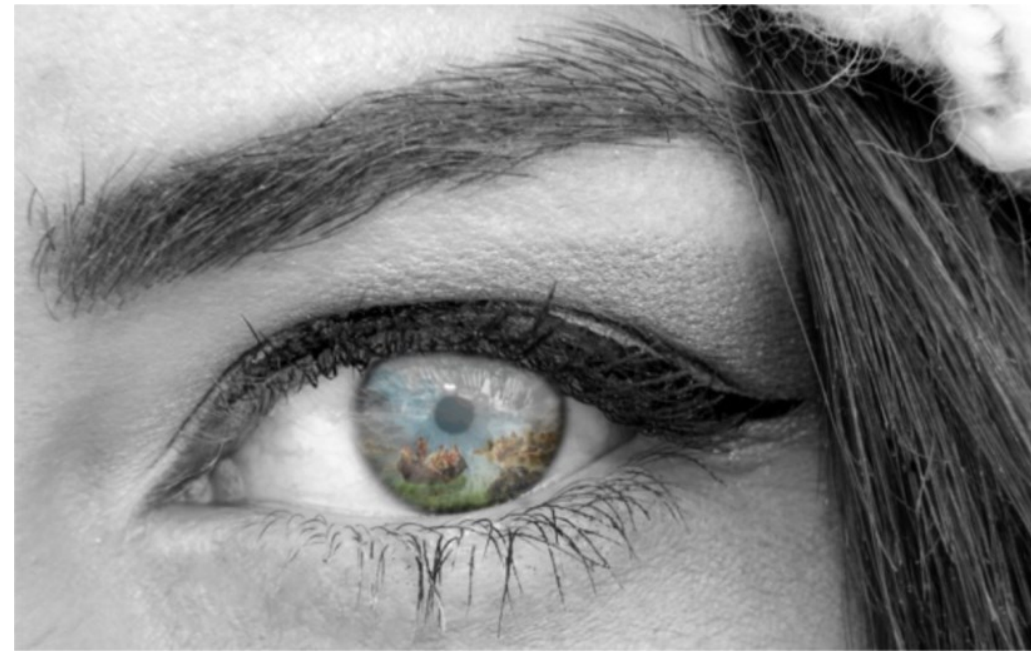

Figur 10. Student I. Referanse til Brudeferden i Hardanger, Adolph Tidemand og Hans Gude (1848). CC BY-NC-ND 4.0

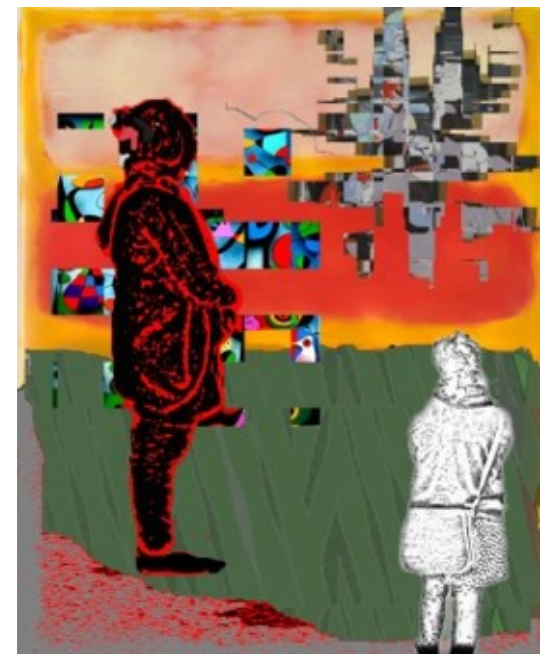

Figur 11. Student J. Referanse til Orange and Yello, Mark Rothko. CC BY-NC-ND 4.0

Student I (figur 10): Når det kommer til publisering av dette bilde så ville det vært innenfor å gjøre. Det eneste bilde jeg har brukt som det er opphavsrett på og som har verkshøyde er Brudeferd i Hardanger. Men det er over 70 år siden Tidemand og Gude døde, og dermed er opphavsretten oppløst. Jeg mener selv at jeg heller ikke har brukt bildet deres på noen krenkende måte ovenfor familie eller kunstnerne selv. Bildet av øyet er hentet fra en nettside under Creative Commons (CCO). Så bilde av øyet trengs det ingen kreditering på, og det er fri for kommersiell bruk.

Student J (figur 11): I bildet har jeg brukt et maleri av Rothko. Bildet viser en opplevelse av min egen erfaring. Søsteren min som ser på et maleri av Vasilij Kandinskij og meg som ser på et maleri av Joan Miró.

I kategorien referanse har flere av studentene vært tro mot den originale historien som verkene forteller. Forelegget utgjør for eksempel en detalj i figur 10, men denne detaljen er sentral for historien. Det er brudefolket i båten, og en betydningsfull kulturell referanse til Brudeferden i Hardanger. Maleriet er satt inn i et fotografi av en brud, og refererer således den originale fortellingen.

Et annet eksempel i kategorien er en scene fra et galleri som refererer til Rothkos kunst, figur 11. Studenten har brukt seg selv som betrakter i bildet, og det er opplevelsen av Rothko, Miró og Kandinskijs bilder som formidles i dette studentarbeidet. Foreleggene fungerer som fargepaletter, og er hver for seg mindre 
Silje Bergman. Kopiering og kulturelle referanser som verktøy i bildeskaping

deler enn det totale bildet. De fremstår altså som sitater i helheten, hvor komposisjon av delene er det bærende i uttrykket, mer enn hvert element som er kopiert.

I disse studentarbeidene har referansene til eksisterende kunst fått en interpikturell kvalitet. De er gjenkjennelige elementer i en ny sammenheng, og de har fått en ny funksjon i sammenstillingen med andre elementer.

\section{Kategori 6 - Inspirasjon}

Inspirasjon i bibelsk tradisjon er at bibelens skrifter ble «innblåst av Gud» (Johnstad, 2016). Inspirasjon blir med dette synet det Gud vil, eller i Guds ånd. Også i kunstnerisk sammenheng er inspirasjon ofte betraktet som noe åndelig. Dette noe som stimulerer og motiverer til kreativitet. I denne studien viser kategorien inspirasjon til arbeider hvor den skapende prosessen har sprunget ut av en impuls fra et annet kunstverk, uten å kopiere elementer direkte. Kategorien skiller seg fra de foregående ved at referansen ikke alltid er tydelig. Utøveren kan ha arbeidet med den bakenforliggende ideen eller inntrykket av verket, fremfor det visuelle uttrykket.

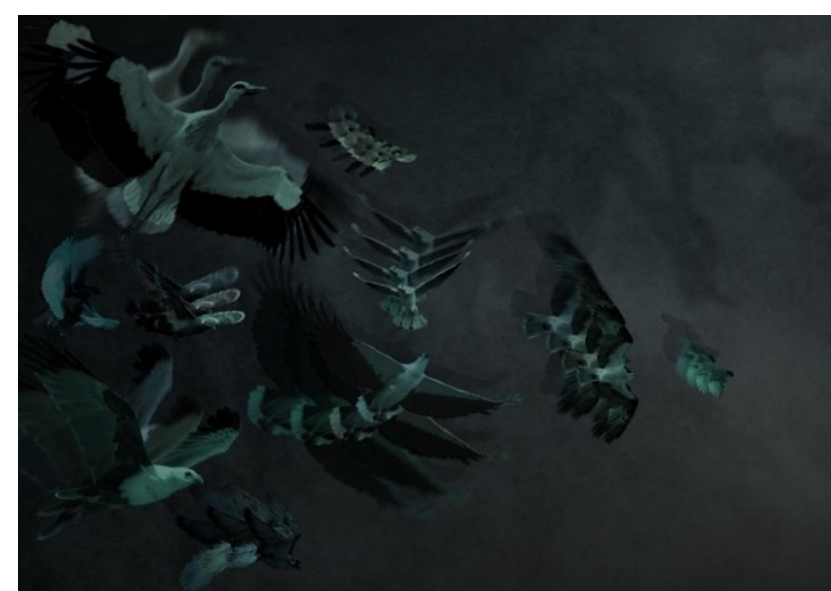

Figur 12. Student K. linspirasjon fra Paul Klee, Dream City (1921) og Fuge in red (1921). CC BY-NC-ND 4.0

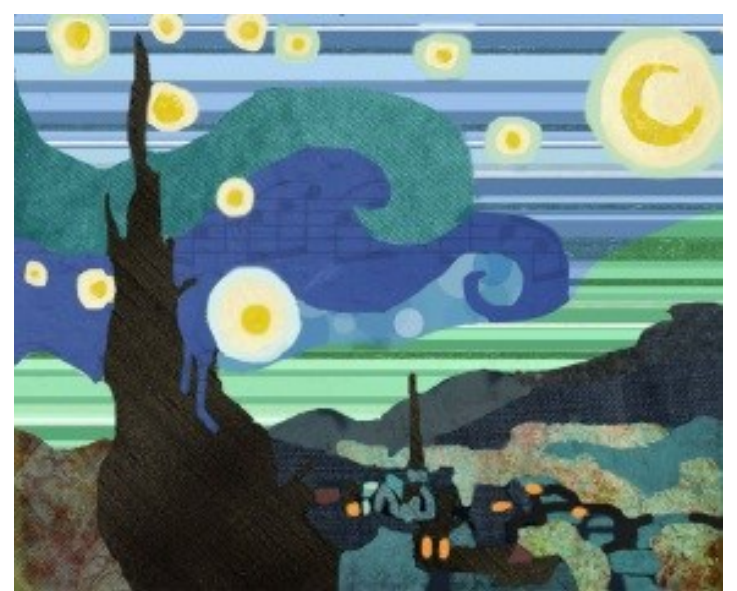

Figur 13. Student L. Inspirasjon fra Vincent van Gogh, Stjernenatt (1889). CC BY-NCND 4.0

Student K (figur 12): Mitt bilde er inspirert av Klees uttrykk, men jeg har brukt helt andre bilder, former, teknikker, virkemiddel og komposisjon. Jeg har skapet noe nytt, ikke en kopi. I tillegg så er det nå mere en 70 år siden Klees død, og av denne grunn er disse verkene ikke lenger beskyttet, ifølge åndsverksloven. Bildene jeg sammenføyet kan fortsatt ha blitt lagt ut ulovlig fra nettstedet jeg hentet bilden fra, det gjelder å være nøye når man søker og i tillegg kanskje se mere nøye etter Creative Commons lisens. Det føles på en måte som om det er mere rett og kun bruke lovlige bilder. 
Silje Bergman. Kopiering og kulturelle referanser som verktøy i bildeskaping

Student $L$ (figur 13): Hvis jeg skal argumentere for at bilde jeg har lagd er et selvstendig verk, må det vel være at jeg har satt det i sammen med utklipp av forskjellige mønster. Det er ikke lenger et maleri, men et slags «lappeteppe». På den andre siden ser man ved første øyekast hvilket bilde som er utgangspunkt. Det er akkurat samme linjer i bildet, og fargene er også i helhet veldig like. Derfor mener jeg at bilde jeg har lagd ikke er veldig selvstendig.

I kategorien inspirasjon skiller studentarbeidene seg gjerne mer fra foreleggene, og refererer foreleggene på andre måter. Resultatene viste for eksempel at kunstnerens stil og formale virkemidler er kopiert, mens motivet ikke er gjenkjennelig. Figur 12 viser interpikturelle referanser til Klees abstrakte ekspresjonisme. Det spiller på repetisjon av objekter i ulike størrelser, valører, fargeklang og transparens, men det er ingen kopi.

På en helt annen måte har motiv og komposisjon vært tydelig inspirasjon og referanse til Van Gogh i figur 13. Ingenting av hans særegne malestil, fargebruk og penselstrøk er kopiert, det er isteden en interpikturell kobling til motivet, bygget opp med ulike «lapper» som skiller seg vesentlig fra forelegget.

\section{Hvordan brukte studentene kopiering og kulturelle referanser som verktøy?}

Eksemplene som er trukket frem for hver kategori, er representative for resultatene i studien. Referansene til de verk som har vært forelegg er fremtredende, og resultatene kan i varierende grad regnes som nye og selvstendige verk. I noen av studentarbeidene er det estetiske uttrykket fra foreleggene fremdeles det mest fremtredende. For eksempel vil en sammenstilling som i figur 3 bygge videre på fortellingen i Libergs skikkelse og Pushwagners militærmaskin, men det er ikke sikkert det estetiske uttrykket i studentarbeidet overdøver det vi kjenner igjen fra originalene. I motsetning vil det estetiske uttrykket som studenten har skapt i figur 11, der Rothkos orange sjanger er gjenkjennelig, overdøve det som er lånt fra forelegget, men fremdeles ha en interpikturell referanse. Resultatene tyder på at studentene har vært frie til å overskride grensene i åndsverkloven, men at de har utnyttet friheten på ulike måter, og anvendt varierte teknikker for å kopiere, klippe, lime og manipulere forskjellige uttrykk til en endret visuell helhet. Studentenes personlige uttrykk kan sies å ligge i manipulasjonene av foreleggene, men det ligger også i valgene de har foretatt gjennom sin skapende prosess. De har valgt å bruke bestemte elementer, men de har også valgt bort deler. Dette har betydning for hvordan vi vurderer kopieringen, og ifølge Goldsmith er det her kreativiteten og originaliteten ligger. 
Silje Bergman. Kopiering og kulturelle referanser som verktøy i bildeskaping

Graden av bearbeidelse innvirker på vurderingen av om det har oppstått et nytt og selvstendig verk. Imidlertid vil ikke det at foreleggene er bearbeidet, i seg selv, være nok til at verket regnes som nytt eller selvstendig i opphavsrettsperspektiv (Rognstad \& Lassen, 2009, s. 123), bearbeidelsen må gi uttrykk for en selvstendig skapende åndsinnsats. Dette (litt vage) kravet må altså konkretiseres for å være anvendelig som en rettledning for undervisning, og i bruk av eksisterende verk som forelegg. Studentarbeidene i denne undersøkelsen er nettopp en konkretisering av gråsonen. De utfordrer forståelsen av hva som er vernet i et åndsverk, hvor langt vernet kan strekkes, og belyser hva slags bearbeidelser som endrer det estetiske uttrykket, og hvilke prosesser som kan føre til at et nytt og selvstendig verk kan oppstå.

\section{Hva slags opphavsrettslige vurderinger gjorde studentene i den skapende prosessen?}

Studentenes opphavsrettslige vurderinger startet allerede i første fase, konstruksjonen, hvor de valgte verk til bruk i bildeskapingen. Noen la strenge bånd på egen frihet, og valgte verk som var falt i det fri, for å ikke krenke opphavers rettigheter. Andre utfordret grensene mer, enten på grunn av arbeidets rammer innenfor en skolekontekst, eller fordi diskusjonene om opphavsrett i forelesningene hadde gjort dem oppmerksomme på at åndsverkloven ikke bare begrenser, men også åpner opp for bruk av vernede verk. Problemstillingene de tok opp i sine refleksjoner handlet mye om i hvilken grad de hadde bearbeidet foreleggene nok til å kalle det endring, bearbeidelse eller nytt og selvstendig verk.

Man kan stille spørsmål om bildeskaping gjennom kopiering styrker studentenes evne til å sette grenser, og til å vurdere hvor grensene er eller bør være.

Refleksjonene viser at det er behov for teoretisk kunnskap om åndsverkloven, men at studentenes forståelse av opphavsrett styrkes gjennom den bildeskapende prosessen. Et viktig resultat var at den skapende interpikturelle prosessen operasjonaliserer mekanismer i åndsverkloven, og derfor skaper refleksjoner og læring som er vanskelig å få til gjennom teori alene. Å tolke paragrafer i åndsverkloven ble altså gjort gjennom konkret og praktisk erfaring. På denne måten blir ikke regler kun uforståelige restriksjoner av deres kreative praksis, slik Lessig uttrykker bekymring for (2009).

Kompetansen dette utvikler bygger på en kombinasjon av praktisk og teoretisk kunnskap, der studenter blir medkonstruktører av kunnskap gjennom aktivitet og refleksjon, i tråd med Paavola og Hakkarainen (2005). Den teoretiske tilgangen til kunnskap er ikke mindre viktig, men forståelse av teorien utvikles gjennom konkret anvendelse av den i en skapende prosess. Jeg vil likevel påpeke at aktivitetene 
Silje Bergman. Kopiering og kulturelle referanser som verktøy i bildeskaping

alene ikke nødvendigvis vil gi trygghet til å vurdere etiske problemstillinger som ligger utenfor det konkrete arbeidet studentene har jobbet med.

Løsningene studentene har kommet frem til i sitt arbeid, har ikke vært feil som svar på oppgaven, eller bruk i en undervisningskontekst. Imidlertid vil noen av studentarbeidene kunne føre til krenkelser av opphavsretten om de skulle brukes i kommersiell sammenheng, eller vises offentlig uten at de er gjenstand for en kritisk og vitenskapelig undersøkelse som denne. Dette er en problemstilling som gjenspeiles i flere av sitatene. Noen sier konkret at arbeidet ikke kan publiseres offentlig, på en blogg eller i sosiale medier, av hensyn til opphavsretten til foreleggene. Ut av slike refleksjoner springer en verdifull læringsprosess, og med den en mulighet for å justere sin forståelse. I alle disse eksemplene har en del av prosessen for studentene handlet om å vurdere eget arbeid med et analytisk blikk på hvilken 'stemme' som snakker høyest i verket. Er det det opprinnelige forelegget som skaper den «estetiske opplevelsen» (Vyrje, 2012) av verket, eller er det den kreative utvelgelsen, sammenstillingen og bearbeidelsen som er det bærende, slik som var målet i for eksempel Uncreative Writing (Goldsmith, 2011).

Student A og B har løst oppgaven på ulike måter, både i valg av forelegg og behandling av elementer. Refleksjonene tyder på at de synes det mangler noe for å være nyskapelser. Hva er så denne mangelen? Student A peker på at det ikke er nok bearbeidet. Student B legger vekt på at foreleggene er gjenkjennelige. Åndsverkloven gir ingen prosentvis mengde bearbeidelse som er påkrevd for nyskapelse. Vi må se et helhetlig uttrykk og inntrykk - en estetisk opplevelse i sammenheng med foreleggenes opphavsrett. Student A har fortrinnsvis brukt verk der vernetiden er utløpt (Åndsverkloven, 2018, § 11) og derfor fritt kan brukes. Student B har derimot brukt forelegg som fremdeles har et opphavsrettslig vern. Denne bruken kan argumenteres for med avgrensningene av opphavers rettigheter, for eksempel § 6 bearbeidelser og § 29 sitater (Åndsverkloven, 2018).

Student $C$ har satt et vernet motiv inn i et av Munchs store malerier som fritt kan brukes i dag. Studenten reflekterer selv over denne bruken av tegneseriefiguren Lucky Luke, og at verket ikke kan publiseres på eksempelvis sosiale medier. Det er riktig at en slik publisering kanskje ville stride mot De Beveres opphavsrett, men på den annen side er dette en referansebruk og en kontekst-flytning med parodiens ironisk vri (Lucky Luke som elg i solnedgang), og kan begrunnes som et ulovfestet unntak fra opphavsretten (Aakre, 2002, s. 86-92; Rognstad \& Lassen, 2009, s. $144,145)$. 
Silje Bergman. Kopiering og kulturelle referanser som verktøy i bildeskaping

Student $\mathrm{G}$ og $\mathrm{H}$ har ulik kritisk forståelse av egen bearbeidelse, og hva som er tilføyet eller har endret det estetiske uttrykket. Student G ser sitt verk som nyskapende mens student $\mathrm{H}$ mener eget arbeid ikke kan publiseres offentlig. Hvis man ser nærmere på innholdet og referansene i det siste av disse blir det tydelig at bearbeidelsene er vesentlige for den estetiske opplevelsen av verket. Det er flere elementer som er viktige i vurderingen av en slik collage. Student $\mathrm{H}$ har skapt et innhold som spiller på Pollocks personlighet og kunstnerskap. Studenten føler selv at bildet som helhet bærer lite preg av å være et nytt uttrykk, men faktum er at studenten har tilført et helt annet innhold, det er en gjennomtenkt komposisjon og fargebruk som gir et klart annet uttrykk enn foreleggene gjør hver for seg. At det er en homage til Pollock taler i tillegg for at dette er lovlig bruk.

\section{Konklusjon}

I denne studien har jeg satt søkelyset på noen viktige men underkommuniserte sider ved digital kompetanse i Fagfornyelsen, og aktualisert opphavsrett og kritisk tenkning på en annen måte enn hvordan dette får fokus i de nye læreplanene. Hovedvekten har ikke ligget på de tekniske ferdighetene ved digital bildebehandling, men på å utvikle kritisk refleksjon knyttet til ulike måter å bruke kopiering og kulturelle referanser på i bildeskaping. Studentene i denne studien brukte kopiering i sine verk som kommunikasjon med symbolikk og referanser til eksisterende verk fra vår felles kulturarv. I denne prosessen utviklet studentene sin interpikturelle litterasitet og et reflektert grunnlag for å være produsenter, heller enn konsumenter, av visuelt materiale i en digital delingskultur.

Å forstå teoretiske kunnskapskilder gjennom konkrete skapende prosesser krever at man aktualiserer og problematiserer det teoretiske så det gir mening for praksis.

Gjennom studentenes refleksjoner over de bildeskapende prosessene og diskusjoner knyttet til de visuelle arbeidene deres, fremsto de interpikturelle prosessene som egnede utgangspunkt for meningsutveksling og vurderinger av opphavsrettslige problemstillinger. Erfaringene styrker studentenes indre navigatør, og bidrar til forståelse av hva som kan være krenkende bruk av åndsverk og hva som må være lov. Denne kompetansen er viktig for studentenes handlingsrepertoar, når de selv skal skape eller undervise om og med eksisterende verk i fremtiden.

\section{Forfatteromtale}

Silje Bergman er PhD-kandidat i Kulturstudier ved Fakultet for humaniora, idretts-og utdanningsvitenskap, Institutt for estetiske fag, Universitetet i Sørøst-Norge. Hun er utdannet faglærer i design, kunst og håndverk fra Høgskolen i Oslo og 
Silje Bergman. Kopiering og kulturelle referanser som verktøy i bildeskaping

Akershus (nå OsloMet) og har en mastergrad i formgiving, kunst og håndverk fra samme universitet.

\section{Referanser}

Aakre, H. (2002). Retten til å sitere fra åndsverk. Fagbokforlaget.

Banks, M. (2007). Visual Methods in Social Research. SAGE Publications.

Bergman, S. (2019). Utfordringer ved bruk og deling av visuelle uttrykk i en digital tidsalder. FormAkademisk, forskningstidsskrift for design og designdidaktikk, 12(1), 1-20. https://doi.org/10.7577/formakademisk.2641

Bjerke, Y. I. L. (2019, 09.12). Lærere dropper å oppgi kildene når de lager materiell til undervisningen: Lærere laster ned, plukker og setter sammen materiell til undervisningen, men glemmer å oppgi kilder. Utdanningsnytt. https://www.utdanningsnytt.no/laererrollen-laereryrket-undervisning/laereredropper-a-oppgi-kildene-nar-de-lager-materiell-til-undervisningen/222363

Bolter, J. D. \& Grusin, R. (1999). Remediation : understanding new media. MIT Press.

Borschke, M. (2011). Rethinking the rhetoric of remix. Media international Australia incorporating Culture \& policy, 141(141), 17-25. https://doi.org/10.1177/1329878X1114100104

Bourriaud, N. (2005). Postproduction (Bd. 2). Lukas \& Sternberg.

Brænne, K. (2009). Mellom ord og handling: om verdsetjing i kunst og handverksfaget. [Doktoravhandling, Arkitektur- og designhøgskolen i Oslo]. Oslo.

Buckingham, D. (2006). Defining digital literacy - What do young people need to know about digital media? Nordic Journal of Digital Literacy, 1(4), 263-277 ER. https://doi.org/10.18261/ISSN1891-943X-2006-04-03

Corbin, J. \& Strauss, A. (2015). Basics of qualitative research: techniques and procedures for developing grounded theory (4. utg.). SAGE Publications.

Dale, E. (2001). Om utdanning : Klassiske tekster. Gyldendal akademisk.

DelRett.no. (2010, 5. februar 2019). Er det lov å bruke bilder i presentasjoner $i$ forelesninger og for publisering på LMS? Hentet 23. april fra https://delrett.no/nb/sporsmal/er-det-lov-å-bruke-bilder-i-presentasjoner-iforelesninger-og-publisering-på-Ims

DelRett.no. (2017). Hvem har ansvaret hvis en elev publiserer vernet materiale på nett? Del Rett Opphavsrett i undervisning. http://delrett.no/nb/sporsmal/hvemhar-ansvaret-hvis-en-elev-publiserer-vernet-materiale-på-nett-0 
Silje Bergman. Kopiering og kulturelle referanser som verktøy i bildeskaping

DelRett.no. (2019, 22. mars 2019). Kan jeg redigere et bilde, modernisere det med digitale medier og bruke det i en bacheloroppgave? Hentet 23. april fra https://delrett.no/nb/sporsmal/kan-jeg-redigere-et-bilde-modernisere-det-meddigitale-medier-og-bruke-det-i-en-0

Dewey, J. \& Wrang, J. (2005). Demokrati og uddannelse. Forlaget Klim.

Emmerling, L. (2003). Jackson Pollock, 1912-1959. Taschen.

Ferrari, A. (2013). DIGCOMP a framework for developing and understanding digital competence in Europe. (EUR 26035 EN). J. R. C. o. t. E. Commission. https://ec.europa.eu/jrc/en/publication/digcomp-framework-developing-andunderstanding-digital-competence-europe

Gilje, Ø., Landfald, Ø. F. \& Ludvigsen, S. (2018). Dybdelæring ; historisk bakgrunn og teoretiske tilnærminger. Bedre skole, 30(4), 22-27.

Giæver, T. H., Johannesen, M. \& Øgrim, L. (2014). Digitale verktøy i skolen ferdigheter, kompetanse, dannelse? I T. H. Giæver, M. Johannesen \& L. Øgrim (Red.), Digital praksis i skolen (s. 10-23). Gyldendal Akademisk.

Goldsmith, K. (2011). Uncreative Writing: Managing Language in the Digital Age. Columbia University Press.

Granlund, M. (2015, 19. mars 2015). Opphavsretten på sin side. Hentet 19.11.2018 fra https://www.fabelaktigformidling.no/verktoy/opphavsretten-p-sin-side

Gulliksen, M. S. (2009). Teaching form quality in craft (Key-Note Speech). I L. K. Kaukinen (Red.), Proceedings of the Crafticulation and Education Conference (Bd. 14, s. 199-206). NordFo Techne A.

Haakonsen, P. (2017). Grunnleggende ferdigheter i kunst og håndverk. FORM, No. 3.

Hakkarainen, K., Hietajärvi, L., Alho, K., Lonka, K. \& Salmela-Aro, K. (2015). Sociodigital Revolution: Digital Natives vs Digital Immigrants. I J. D. Wright (Red.), International Encyclopedia of the Social \& Behavioral Sciences (Bd. 22, s. 918-923). Elsevier. https://doi.org/10.1016/B978-0-08-097086-8.26094-7

Hannemyr, G. (2018). Opphavsrett og bruk av verk i undervisningssektoren. Creative Commons arkiv. http://cc-arkiv.ngoweb.no/node/33

Hellesnes, J. (2001). Sosial konstruktivisme i vitskapsteorien. Nytt norsk tidsskrift, 18(2), 132-149.

Hubbard, G. (2003). Artistic homage. (Teaching art with art).(art project). Arts \& Activities, 133(5), 24.

Häikiö, T. (2007). Barns estetiska läroprocesser: atelierista i förskola och skola [Doktorgradsavhandling Göteborgs universitet]. Göteborgs universitetsbibliotek GUP. https://gup.ub.gu.se/file/207079 
Silje Bergman. Kopiering og kulturelle referanser som verktøy i bildeskaping

Illeris, H. (2000). Copying - You just aren't supposed to do that! I L. Lindström (Red.), The cultural context. Comparative studies of art education and children's drawings. Stockholm Institute of Education Press.

Iordache, C., Mariën, I. \& Baelden, D. (2017). Developing Digital Skills and Competences: A Quick-Scan Analysis of 13 Digital Literacy Models. Italian Journal of Sociology of Education, 9(1), 6-30.

https://doi.org/doi:10.14658/pupj-ijse-2017-1-2

Jensen, R. \& Leirvik, C. H. (2015). Elevsamtalen, læringsdialog og vurdering (Bd. [14]). Gyldendal akademisk.

Johannessen, L., T. Rafoss., E. B. Rasmussen. (2018). Hvordan bruke teori? : Nyttige verktøy i kvalitativ analyse. Universitetsforlaget.

Johnstad, G. (2016). Skriften - Guds normative og autoritative ord, del 2. Hentet 10.06 fra https://www.foross.no/hva-tror-vi/skriften-guds-normative-ogautoritative-ord-del-2/

Jurgenson, N. (2019). The social photo : on photography and social media. http://search.ebscohost.com/login.aspx?direct=true\&scope=site\&db=nlebk\&db $=$ nlabk \&AN=1595190

Kristeva, J. (1980). Desire in Language: A Semiotic Approach to Literature and Art (T. Gora, Overs.; L. S. Roudiez, Red.). Columbia University Press.

Kunnskapsdepartementet. (2017). Overordnet del - verdier og prinsipper for grunnopplæringen. https://www.regjeringen.no/no/dokumenter/verdier-ogprinsipper-for-grunnopplaringen/id2570003/

Lamb, B. (2007). Dr. Mashup or, Why Educators Should Learn to Stop Worrying and Love the Remix. EDUCAUSE Review.

https://eric.ed.gov/?q=Dr.+Mashup+or\%2c+Why+Educators+Should+Learn+to +Stop+Worrying+and+Love+the+Remix\&id=EJ769396

Larsen, O. F. (1991). Kopiere-Jamen det må man da ikke! Formning/Billedpedagogisk Tidsskrift, (No 3), 19-21.

Lessig, L. (2009). Remix: Making Art and Commerce Thrive in the Hybrid Economy. The Penguin Press. https://doi.org/10.5040/9781849662505

McClimans, E. (2018). Ny åndsverklov - noe å si for delingskulturen i skolen? Norsk lektorlag. https://www.norsklektorlag.no/juridisk-talt/ny-andsverklov-noe-a-sifor-delingskulturen-i-skolen-article1872-177.html

Mikkelsen, R. \& Rist, M. V. P. (2018). Lærerstudenters digitale praksismøte. I L. B. Johanson \& S. S. Karlsen (Red.), Restart: $\AA$ være digital $i$ skole og utdanning (s. 163-177). Universitetsforlaget.

Nielsen, L. M. (2019). Fagdidaktikk for kunst og håndverk : i går, i dag, i morgen (2. utgave. utg.). Universitetsforlaget. 
Silje Bergman. Kopiering og kulturelle referanser som verktøy i bildeskaping

NSD. (2017). Originalitet og plagiat i kulturfeltet (37616, 40143, 52560) [Research]. http://pvo.nsd.no/prosjekt/52560

Paavola, S. \& Hakkarainen, K. (2005). The Knowledge Creation Metaphor - An Emergent Epistemological Approach to Learning. Contributions from History, Philosophy and Sociology of Science and Mathematics, 14(6), 535-557. https://doi.org/10.1007/s11191-004-5157-0

Paavola, S., Lipponen, L. \& Hakkarainen, K. (2004). Models of Innovative Knowledge Communities and Three Metaphors of Learning. Review of Educational Research, 74(4), 557-576. https://doi.org/10.3102/00346543074004557

Postholm, M. B. (2010). Kvalitativ metode. En innføring med fokus på fenomenologi, etnografi og kasusstudier (Bd. 2). Universitetsforlaget.

Rian, H. O. (2018, 7. mai). Åndsverksloven må gjelde også i klasserommet. Dagsavisen. https://www.dagsavisen.no/debatt/andsverksloven-ma-gjeldeogsa-i-klasserommet-1.1140635

Rognstad, O. A. \& Lassen, B. S. (2009). Opphavsrett. Universitetsforlaget.

Rostama, G. (2015). Remix Culture and Amateur Creativity: A Copyright Dilemma. WIPO magazine. http://www.wipo.int/wipo magazine/en/2015/03/article 0006.html

Smith-Meyer, T. (2020). Vederlag. Kopinor.no. https://www.kopinor.no/vederlag

Solvig, M. (2010). Opphavsrett. https://digitalskole.wordpress.com/digitaleutfordringer/opphavsrett/

Stana, I. (2017). Opphavsrett i klasserommet. FORM, 51(5), 12-13.

Tjora, A. H. (2017). Kvalitative forskningsmetoder i praksis (3. utg.). Gyldendal akademisk.

Torvund, O. (2012, 10. januar). Når et verk faller i det fri. Olav Torvunds blogg. https://blogg.torvund.net/2012/01/10/nar-et-verk-faller-i-det-fri/

Utdanningsdirektoratet. (2012). Rammeverk for grunnleggende ferdigheter. Udir. https://www.udir.no/globalassets/upload/larerplaner/lareplangrupper/rammever k grf 2012.pdf

Utdanningsdirektoratet. (2018). Rammeverk for lærerens profesjonsfaglige digitale kompetanse (PfDK). Udir. https://www.udir.no/kvalitet-ogkompetanse/profesjonsfaglig-digital-kompetanse/rammeverk-larerensprofesjonsfaglige-digitale-komp/kompetanseomradene/

Utdanningsdirektoratet. (2019a). Dybdelæring. Udir. https://www.udir.no/laring-ogtrivsel/dybdelaring/

Utdanningsdirektoratet. (2019b). Grunnleggende ferdigheter Kunst og håndverk (KHV01-02). Kunnskapsdepartementet. https://www.udir.no/lk20/khv01-02/omfaget/grunnleggende-ferdigheter?curriculum-resources=true 
Silje Bergman. Kopiering og kulturelle referanser som verktøy i bildeskaping

Utdanningsdirektoratet. (2019c). Høringsdokument, Læreplan i kunst og visuelle verkemiddel. Udir. https://hoering.udir.no/Hoering/v2/354?notatld=730

Veiteberg, J. (1982). Skaping eller gjenskaping. Nokre tolkingsproblem i samband med Lena Cronqvist sine bilete. Kunst og kultur, 66(2), 113-128.

Veiteberg, J. (2009). Kunsten å låna - om ei platte av Irene Nordli. Kunst og kultur, 92(1), 3-13. https://doi.org/10.18261/ISSN1504-3029-2009-01-02

Vyrje, M. S. (2012). Åndsverk og plagiat - noen refleksjoner. Jussens Venner, 47(1), 69-81. https://doi.org/10.18261/ISSN1504-3126-2012-01-03

Vyrje, M. S. (2017). Copyright and Aesthetic Experience. Nordiskt immateriellt rättsskydd, (2), 147-169. https://www.nir.nu/journals/downloadsection/12292

Wadel, C. (1991). Feltarbeid $i$ egen kultur : En innføring i kvalitativt orientert samfunnsforskning. SEEK.

Wadel, C. \& Fuglestad, O. L. (2014). Feltarbeidsprosessen. I C. Wadel, C. C. Wadel \& O. L. Fuglestad (Red.), Feltarbeid i egen kultur (s. 211-238). Cappelen Damm akademisk

Wessel-Aas, J. (2016). Opphavsrett, fotorett og personbilder i nettjournalistikk. Cappelen Damm.

Yin, R. K. (2009). Case Study Research. Design and Methods (4. utg.). SAGE Publications.

Åndsverkloven. (2018). Andsverkloven, Lov om opphavsrett til åndsverk mv. (LOV2018-06-15-40). Lovdata. https://lovdata.no/dokument/NL/lov/2018-06-15-40 